Synthesis, part of a Special Feature on Sustainable Land-Use Practices in Mountain Regions: Integrative Analysis of Ecosystem Dynamics Under Global Change, Social-Economic Impacts, and Policy Implications

\title{
Sustainable Land Use in Mountain Regions Under Global Change: Synthesis Across Scales and Disciplines
}

\author{
$\underline{\text { Robert Huber }}^{1}, \underline{\text { Andreas Rigling }}^{1}, \underline{\text { Peter Bebi }}^{2}$, Fridolin Simon Brand $^{3}$, Simon Briner $^{4}$, Alexandre Buttler ${ }^{5,6}$, Ché Elkin $^{7}$,

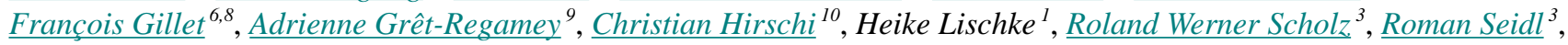 \\ Thomas Spiegelberger ${ }^{5,11}$, Ariane Walz ${ }^{12,13}$, Willi Zimmermann ${ }^{10}$ and Harald Bugmann ${ }^{7}$
}

ABSTRACT. Mountain regions provide essential ecosystem goods and services (EGS) for both mountain dwellers and people living outside these areas. Global change endangers the capacity of mountain ecosystems to provide key services. The Mountland project focused on three case study regions in the Swiss Alps and aimed to propose land-use practices and alternative policy solutions to ensure the provision of key EGS under climate and land-use changes. We summarized and synthesized the results of the project and provide insights into the ecological, socioeconomic, and political processes relevant for analyzing global change impacts on a European mountain region. In Mountland, an integrative approach was applied, combining methods from economics and the political and natural sciences to analyze ecosystem functioning from a holistic human-environment system perspective. In general, surveys, experiments, and model results revealed that climate and socioeconomic changes are likely to increase the vulnerability of the EGS analyzed. We regard the following key characteristics of coupled human-environment systems as central to our case study areas in mountain regions: thresholds, heterogeneity, trade-offs, and feedback. Our results suggest that the institutional framework should be strengthened in a way that better addresses these characteristics, allowing for (1) more integrative approaches, (2) a more network-oriented management and steering of political processes that integrate local stakeholders, and (3) enhanced capacity building to decrease the identified vulnerability as central elements in the policy process. Further, to maintain and support the future provision of EGS in mountain regions, policy making should also focus on projectoriented, cross-sectoral policies and spatial planning as a coordination instrument for land use in general.

Key Words: adaptive management; climate change; ecosystem services; experiments; interdisciplinary research; land-use change; modeling; transdisciplinary research

\section{INTRODUCTION}

Mountains are the 'undervalued ecological backbone of Europe' (Hazeu et al. 2010) and provide essential ecosystem goods and services (EGS) for both mountain dwellers and people living outside these areas. The capacity of mountain ecosystems to provide key services is however at risk (NoguésBravo et al. 2007, McCain and Colwell 2011). Not only is global warming expected to have rapid and sometimes critical impacts on terrestrial ecosystems in the coming decades (Malcolm et al. 2006, Kurz et al. 2008), but changes in political decision making at different levels and in socioeconomic boundary conditions will also affect land use (Rounsevell et al. 2006, Bugmann et al. 2007). These transitions pose great ecological and societal challenges, requiring the management of the impacts on species composition and ecosystem functioning, and thus the impacts on the provision of EGS (MEA 2005, Schröter et al. 2005, Metzger et al. 2006).
In view of these impending changes, coupled humanenvironment research (Scholz and Brand 2011) is needed with a focus on interactions between humans and the natural environment across spatial and temporal scales (Carpenter et al. 2009a). The Mountland project addressed this need by performing inter- and transdisciplinary research in the Swiss Alps. The aim was to develop land-use practices and alternative policy solutions that ensure the provision of EGS from agricultural and forest land use in mountain regions subject to climate and land-use changes. The expertise and methodological background of nine research groups from the natural sciences, economics, and political sciences were integrated in a research process described in more detail in the introductory article of this Special Feature (Huber et al. 2013a).

In particular, Mountland examined feedback and feedback loops within and between studied human and environmental

\footnotetext{
${ }^{1}$ Swiss Federal Institute for Forest, Snow and Landscape Research WSL, ${ }^{2}$ WSL Institute for Snow and Avalanche Research SLF, ${ }^{3}$ Natural and Social Science Interface, Department of Environmental Systems Science, ETH Zurich, ${ }^{4}$ Agri-food and Agri-environmental Economics Group, Department of Environmental Systems Science, ETH Zurich, ${ }^{5}$ Ecole Polytechnique Fédérale de Lausanne EPFL, School of Architecture, Civil and Environmental Engineering ENAC, Laboratory of ecological systems ECOS, ${ }^{6}$ Université de Franche-Comté-CNRS, ${ }^{7}$ Forest Ecology, Department of Environmental Systems Science, ETH Zurich, ${ }^{8}$ Ecole Polytechnique Fédérale de Lausanne EPFL, School of Architecture, Civil and Environmental Engineering ENAC, ${ }^{9}$ Spatial and Landscape Development, Department of Civil, Environmental and Geomatic Engineering, ETH Zurich, ${ }^{10}$ Environmental Policy and Economics, Department of Environmental Systems Science, ETH Zurich, ${ }^{11}$ Irstea, Research Unit Mountain Ecosystems, ${ }^{12}$ Potsdam Institute for Climate Impact Research PIK, ${ }^{13}$ Institute for Earth and Environmental Science, University of Potsdam
} 
Fig. 1. Map of the European Alps including location and characterization of the three MOUNTLAND case study regions. The spatial-explicit modeling focused on the core zone (dark red). The circular surfaces (brighter red, transparent) indicate the areas of application, including the locations of some of the plotscale experiments (map produced by A. Psomonas, WSL).

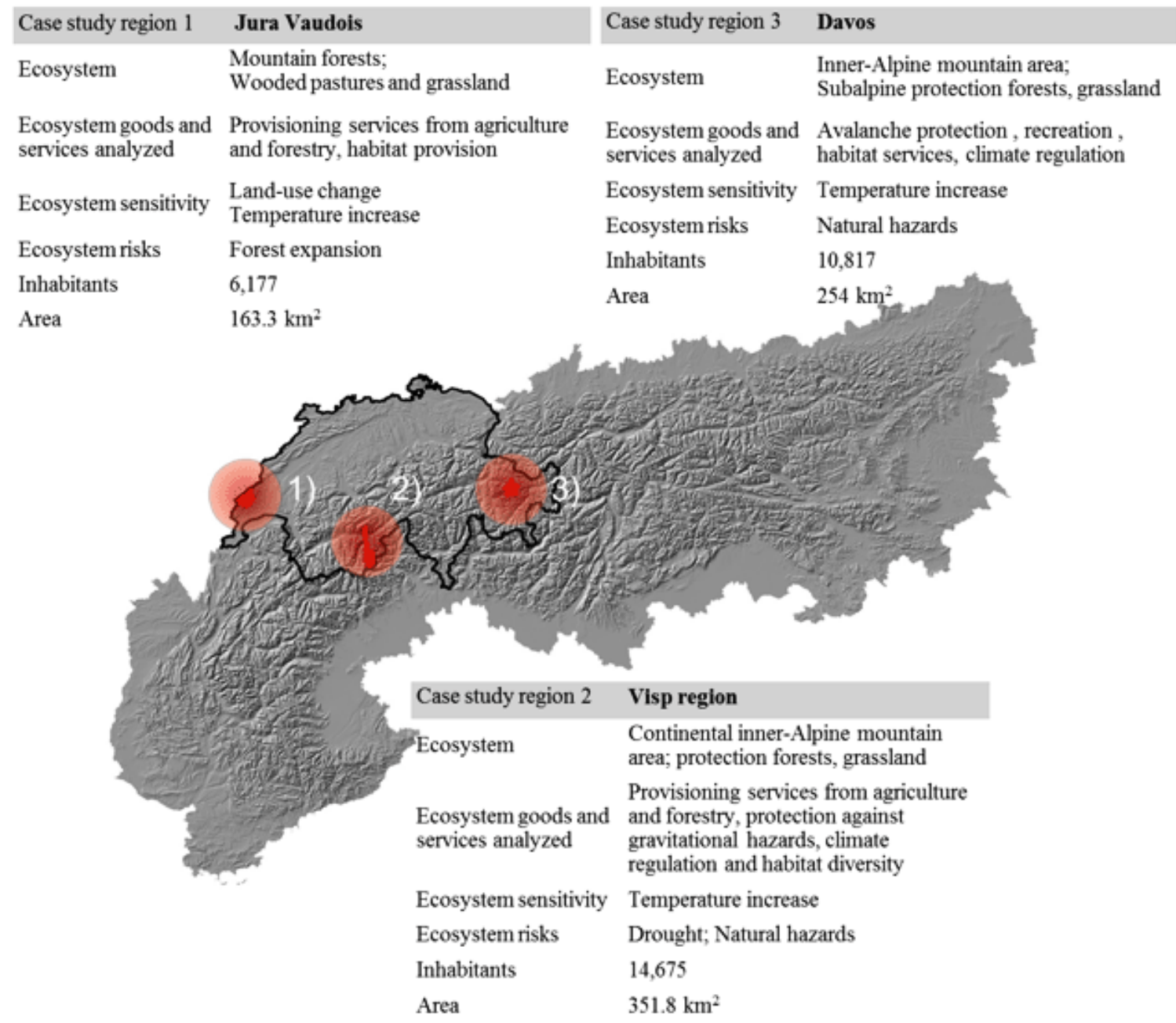

systems (Liu et al. 2007a, Carpenter et al. 2009a) by integrating plot-based observational and experimental evidence in a modeling framework and then upscaling it to the landscape level. Because of the model-based upscaling, small scale environmental changes could be linked with different institutional scales addressing the use and management of the corresponding ecosystems (Cash et al. 2006, Kok and Veldkamp 2011).

The project focused on three case study regions, namely a pasture-woodland landscape in the Jura, a drought-sensitive inner-alpine region in Valais, and the temperature-sensitive high-alpine region of Davos (Fig. 1).

We summarized and synthesized the results of the Mountland project and provide insights into the ecological, socioeconomic, and political processes relevant for analyzing global change impacts on a European mountain region. First, along with results from the case study regions, we address the effects of climate and land-use changes on EGS provision on different scales and describe regional institutional settings dealing with these changes. For each case study region, we consecutively present the integrated findings from ecological experiments, mechanistic models of landscape dynamics, socioeconomic land-use models, and policy analysis in accordance with the conceptual framework presented in Huber et al. (2013a). Complying with Liu et al. $(2007 a, b)$, we describe four typical characteristics of coupled humanenvironment systems, i.e., nonlinearities and thresholds, heterogeneity, trade-offs, and feedback, for each case study region. Second, we evaluate the results of the project with 
Table 1. Research foci and methodologies in the wooded pastures of the Jura Mountains.

\begin{tabular}{|c|c|c|c|c|c|}
\hline \multirow[t]{2}{*}{ Research Field } & \multirow[t]{2}{*}{ Research Foci } & \multicolumn{3}{|c|}{ Methodology } & \multirow[t]{2}{*}{ References } \\
\hline & & $\mathrm{S}$ & $\mathrm{E}$ & M & \\
\hline \multirow[t]{4}{*}{ Ecology } & $\begin{array}{l}\text { Diachronic and synchronic comparative studies } \\
\text { at landscape scale: identifying patterns, } \\
\text { integrated trends and issues in wooded pastures } \\
\text { of the Jura Mountains. }\end{array}$ & $\mathrm{x}$ & $\mathrm{x}$ & & Buttler et al. 2009, Chételat et al. 2013 \\
\hline & $\begin{array}{l}\text { Fine-scale monitoring and manipulative field } \\
\text { experiments to improve the understanding of } \\
\text { environmental determinants of tree } \\
\text { establishment, growth, and mortality as well as } \\
\text { the impact of cattle activities on vegetation, } \\
\text { habitat use, and soils. }\end{array}$ & $\mathrm{x}$ & $\mathrm{x}$ & & $\begin{array}{l}\text { Kohler et al. 2004a,b, 2006a,b, Smit et al. 2005, } \\
\text { Vandenberghe et al. 2006, 2007, 2008, 2009, } \\
\text { Gillet et al. } 2010\end{array}$ \\
\hline & $\begin{array}{l}\text { Assessment of carbon fluxes, soil respiration, } \\
\text { aboveground and belowground biomass, } \\
\text { community structure, \& dynamics under climate } \\
\text { change. }\end{array}$ & & $\mathrm{x}$ & & Gavazov et al. 2013 \\
\hline & $\begin{array}{l}\text { Spatially explicit, hierarchical modeling of } \\
\text { landscape dynamics considering grassland } \\
\text { dynamics and grazing effects. }\end{array}$ & & & $\mathrm{x}$ & $\begin{array}{l}\text { Gillet 2008, Gillet et al. 2010, Peringer et al. } \\
2013\end{array}$ \\
\hline Ecology \& & Modeling social-ecological feedbacks in the & & & $\mathrm{x}$ & Huber et al. 2012, 2013b Buttler et al. 2012 \\
\hline Socioeconomics & $\begin{array}{l}\text { implementation of payments for environmental } \\
\text { services in pasture-woodlands. }\end{array}$ & & & & \\
\hline \multirow[t]{2}{*}{ Policy } & $\begin{array}{l}\text { Role of agricultural policy network in the } \\
\text { support of wooded pastures. }\end{array}$ & $\mathrm{x}$ & & & Hirschi et al. 2012 \\
\hline & $\begin{array}{l}\text { Governance modes of adaptation measures in } \\
\text { Canton Jura. }\end{array}$ & $\mathrm{x}$ & & & Widmer and Hirschi, unpublished manuscript \\
\hline
\end{tabular}

$\mathrm{S}=($ Field $)$ Survey $; \mathrm{E}=$ Experiments $\mathrm{M}=$ Modeling

respect to policy processes of predominantly national policies with high impact on land use in mountain areas, i.e., agricultural and forest policies, and discuss alternative policy instruments and measures with respect to the four humanenvironment characteristics of each case study region.

\section{WOODED PASTURES OF THE JURA MOUNTAINS}

The main challenge facing the silvopastoral system in the Jura is the segregation between forest and grassland management resulting in a loss of biodiversity and agricultural provisioning services. The main question was how climate change affects these ecosystems, and what agricultural management and policy measures would counteract the loss of these EGS. Table 1 summarizes the research foci, methodologies, and publications pertaining to the Jura region case study.

The analysis of herbaceous production in a transplantation experiment showed that a slight increase in air temperature may be beneficial for forage production in the more coldadapted vegetation of wooded pastures, but drought associated with higher temperatures may have the opposite effect in large open pastures because of the evaporative loss of soil moisture (Gavazov et al. 2013). Insulating tree canopy cover, as well as structural landscape diversity, endows wooded pastures with a buffering potential in the face of climate change in the forthcoming decades. In contrast, open pastures will suffer from a decline in the storage of soil organic carbon because of the leaching of dissolved organic carbon after drought events and a decrease of soil biological activity, which in turn will affect soil fertility. Thus, our experiments suggest that compared to open pastures, wooded pastures are highly resistant to climate change in terms of their carbon cycle.

The integration of these findings in a simulation framework allowed for a transfer to the landscape level. Simulations predict delayed, but inevitable, structural changes of the landscape mosaic. Results from a scenario analysis (Peringer et al. 2013) imply that future moderate warming further supports segregation of the pasture-mosaic into closed forest, sparsely wooded pasture, or grassland. More extreme warming may even homogenize the landscape pattern in the long run if no adaptive management is undertaken. This will have a considerable impact on EGS provision: summer droughts are expected to strongly reduce forage production and wood production will decline because of a species shift from currently dominating Norway spruce (Picea abies) to either 
beech (Fagus sylvatica) under moderate warming, or Scots pine (Pinus sylvestris) under strong warming.

With respect to future land use, we found that farmers in the Jura Mountains are unlikely to increase the number of large domestic herbivores on their farms, even though this would be needed to maintain the ecosystem under climate change. Results from an agent-based farm model integrating socioeconomic driving forces and the above-mentioned ecological modeling framework (Huber et al. 2013b) suggest that economic incentives, in the form of payments for ecosystem services, counteract land-use segregation to a certain extent. However, the long-term consequences of a change in economic incentives depend on historical and current land use as well as on ecological boundary conditions. For example, in areas that are currently used less intensively, a future increase in stocking density might not suffice to change long-term vegetation dynamics and selective tree felling might be necessary (Peringer et al. 2013).

At the policy level, our analysis showed that current agricultural policy supports the ongoing trend to segregate land use, leading to a loss of the wooded pasture ecosystems (Chételat et al. 2013). In general, Swiss agricultural policy supports less intensive agricultural land-use practices because land-use intensification is generally seen as a driver for loss of biodiversity in mountain regions (Zimmermann et al. 2010, Marini et al. 2011). However, wooded pastures are a specific case in which biodiversity conservation often demands an increase of land-use intensities rather than a decrease. Because agricultural policy in Switzerland is highly centralized at the federal level, such very specific characteristics are not always taken into account even though our analysis showed that the agricultural policy network in Switzerland would probably support a policy combining agricultural production with the promotion of biodiversity (Hirschi et al. 2013).

\section{Nonlinear dynamics and thresholds}

Interactions between land-use practices, i.e., grazing, and vegetation dynamics lead to thresholds resulting in different vegetation cover at a small spatial scale $(<1 \mathrm{ha})$ and produce heterogeneous landscapes (Chételat et al. 2013). Nonlinear dynamics are particularly pronounced in the dependence of fodder production on the mosaic structure and the resistance of trees in different development stages to cattle activity (Fig. 2). For example, Norway maple (Acer pseudoplatanus) and beech seedlings ( $<1$ year old) were found to have lower survival and growth rates than Norway spruce and silver fir (Abies alba). Once the seedlings ( $<1$ year old) have developed to saplings (1-3 years), the relative impact of cattle activity on survival and growth rates is higher for silver fir and Norway spruce (Vandenberghe et al. 2007). Transferred to the landscape scale, the simulation of forest dynamics suggests a considerable shift in species composition and tree density as a result of climate change (Peringer et al. 2013). Irrespective of the management alternatives, ecosystems will be unable to return fully to their former state and new states will develop (Huber et al. 2013b).

Fig. 2. Illustrative example of nonlinearities and thresholds in a Swiss mountain wooded pasture: impact of cattle activity on seedlings ( $<1$ year old), saplings ( $1-3$ years), and browsed trees (4-8 years) relative to other survival and growth limiting factors. Trees were exposed to low (solid line) and high (dotted line) grazing pressures. Arrows indicate a higher (up) or lower (down) impact of cattle, which varies by deciduous (Acer pseudoplatanus, Fagus sylvatica) and coniferous species, (Picea abies and Abies $a l b a)$. The impact of grazing increases with higher development stages and high grazing pressure. In contrast, low grazing pressure reduces the relative importance once the seedlings have developed to browsed trees. Deciduous species are generally more vulnerable to cattle activity, with the exception of the sapling stage when coniferous species are more sensitive. With changing management regimes, different tree species will show nonlinear survival and growth rates that may result in species shift under changing climatic conditions.

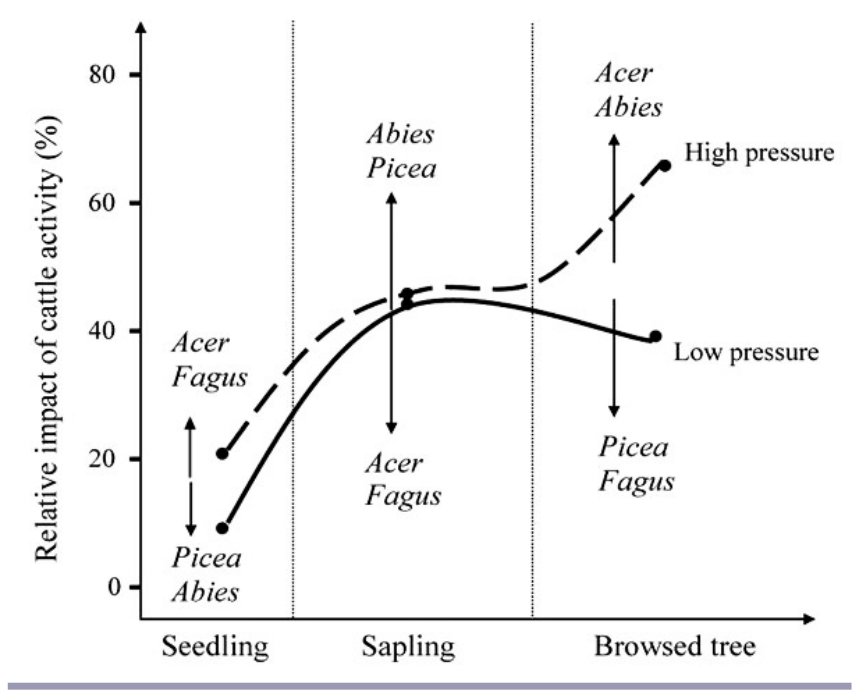

\section{Heterogeneity}

In wooded pastures, the complex interactions between herbaceous and woody plant species as well as land-use intensity lead to high spatial variability even within agricultural production units (paddocks sensu Allen et al. 2011). Fundamentally, this heterogeneity of vegetation dynamics in pasture-woodlands promotes biodiversity (Gillet et al. 1999, Dufour et al. 2006) and three spatio-temporal scales must be considered to understand it. At the landscape scale, habitat selection by cattle kept in paddocks is constrained by human infrastructure, e.g., fences and water points, and natural 
structures, e.g., slopes and open spaces (see Kohler et al. 2006a). At an intermediate scale, i.e., a few square meters, cattle choose those plant communities that are easiest to forage and that feature the best pastoral value (Kohler et al. 2004a). At the finest scale, i.e., within a given vegetation community, cattle avoid dung pats and unpalatable plants (Smit et al. 2005), create disturbances that promote species turnover (Kohler et al. 2006b, Gillet et al. 2010), and determine tree regeneration (Vandenberghe et al. 2006). Thus, management alternatives focusing on just one of these dimensions, e.g., cattle management, will fail to properly address issues related to vegetation dynamics and thus EGS provision.

\section{Trade-offs}

Wooded pastures are a specific case in which biodiversity conservation demands a certain level of land-use intensity. Not surprisingly, our simulation results reveal a positive relationship between the maintenance of biodiversity and agricultural production. Thus, there is a potential win-win situation in food production and biodiversity conservation. As Hirschi et al. (2013) show in their analysis of the Swiss agricultural policy network, such constellations offer an opportunity to achieve a further greening of agricultural policy. However, more general policy developments, such as more open agricultural markets, make an implementation of spatially specific economic incentives challenging even though simulation results suggest that new measures could counteract the loss of biodiversity to a degree (Huber et al. 2013b).

\section{Feedback and feedback loops}

Given the predicted climate change and the present land-use intensity (Peringer et al. 2013), sustainable use of wooded pastures seems compromised. Explicit consideration of the feedback loop between structural changes in farming and vegetation dynamics in a modelling framework revealed a distinctly different landscape pattern compared to a simulation in which climate change effects had been addressed in isolation (Huber et al. 2013b). In addition, the evaluation of feedback revealed important spatial differences leading to losses and gains of habitats in different locations, as also shown, for example, by Claessens et al. (2009) or Polasky et al. (2008). Despite this feedback, the model-based assessment of wooded pastures foresees less heterogeneity and a trend toward a uniform land cover in the long run. Thus, a loss of ecosystem diversity is expected in this case study region.

\section{Summary}

The assessment of climate and land-use changes in the Jura region suggests that the ecological resistance of fine-grained, patterned pasture-woodland landscape may be ousted by pathdependent farm development. Together, these processes may lead to a more vulnerable agricultural production sector and a loss of biodiversity in the long run. Thus, the case study of a silvopastoral landscape reveals the importance of a concomitant consideration of climate and land-use changes in the assessment of EGS in mountain regions (Schröter et al. 2005, Abildtrup et al. 2006).

\section{DRY ALPINE REGION, VISP}

The EGS addressed in the Visp region were the provision of goods by agriculture and forestry, protection against gravitational hazards, climate regulation, and habitat diversity. The main question in the drought-prone ecosystems in central Valais was whether management could improve the resistance and resilience of ecosystems to maintain the provision of these EGS under changes in climate and land use. Table 2 summarizes the research foci, methodologies, and publications pertaining to the Visp case study region.

Ecological experiments and vegetation surveys in the Valais showed that climate change is likely to have considerable impacts on tree regeneration, growth, mortality, and hence on forest dynamics. This effect can be observed not only in the dry parts of European mountain regions but also worldwide (Allen et al. 2010). Ecological experiments and vegetation surveys in Valais showed that climate change is likely to have considerable impacts on tree regeneration, growth, and mortality and hence on forest dynamics not only in the dry parts of European mountain regions but also worldwide (Allen et al.2010). To date, tree mortality has occurred predominantly at lower elevations on particularly dry sites after drought years (Rigling et al. 2013). In a dry pine forest showing droughtinduced mortality, the trees were able to recover after several years of reduced drought in the area (Eilmann et al. 2010, 2011). This clearly demonstrates the elasticity of native trees and their ability to cope with climate extremes and variability. Multiple drought years are however likely to accelerate tree mortality processes in native tree species. Experiments and surveys found that native trees are less resistant to drought than introduced nonnative species (Eilmann and Rigling 2012), among other things, with respect to early seedling growth and survival (Richter et al. 2011).

The insights from these experiments were used to calibrate forest models of climate impacts at the landscape scale. At lower elevations, the increase in drought is projected to result in a significant reduction in forest biomass after multiple dry years (Zweifel et al. 2009, Elkin and Bugmann 2010, Eilmann and Rigling 2012). Forests at middle to higher elevations are, however, expected to benefit from the longer vegetation period predicted and generally higher temperatures, thus fostering forests' provision of services.

To assess the potential for mitigating negative impacts on EGS, we simulated different management options to increase stand heterogeneity and tree resistance against drought, such as overstory and understory thinning, grazing, and gap creation (Fig. 3). Grazing was introduced as an alternative management measure because results from experimental understory thinning and shrub removal showed that water consumption 
Table 2. Research foci and methodologies in the dry alpine region Visp.

\begin{tabular}{|c|c|c|c|c|c|}
\hline \multirow[t]{2}{*}{ Research Field } & \multirow[t]{2}{*}{ Research Foci } & \multicolumn{3}{|c|}{ Methodology } & \multirow[t]{2}{*}{ References } \\
\hline & & $\mathrm{S}$ & $\mathrm{E}$ & M & \\
\hline \multirow[t]{6}{*}{ Ecology } & $\begin{array}{l}\text { Impact of drought on growth and mortality of } \\
\text { mature trees. Adaptive potential to drought of } \\
\text { native and non-native tree species. }\end{array}$ & $\mathrm{x}$ & $\mathrm{x}$ & & $\begin{array}{l}\text { Bigler et al. 2006, Brunner et al. 2009, Dobbertin } \\
\text { et al. 2010, Eilmann et al. 2010, 2011, Eilmann } \\
\text { and Rigling 2012, Rigling et al. 2013. }\end{array}$ \\
\hline & $\begin{array}{l}\text { Effects of drought on inter-specific competition, } \\
\text { insects, pathogens, parasites and its impact on } \\
\text { growth and mortality of mature trees. }\end{array}$ & $\mathrm{x}$ & $\mathrm{x}$ & & $\begin{array}{l}\text { Weber et al. 2008a, Wermelinger et al. 2008, } \\
\text { Zweifel et al. 2009, Rigling et al. 2010, Heiniger } \\
\text { et al. } 2011\end{array}$ \\
\hline & $\begin{array}{l}\text { The role of disturbances, climate and } \\
\text { competition on forest regeneration. }\end{array}$ & $\mathrm{x}$ & $\mathrm{x}$ & & Moser et al. 2010, Richter et al. 2012 \\
\hline & $\begin{array}{l}\text { Impact of past forest management such as } \\
\text { grazing or litter raking on forest dynamics. }\end{array}$ & $\mathrm{x}$ & & $\mathrm{x}$ & Weber et al. 2008b, Gimmi et al. 2010 \\
\hline & $\begin{array}{l}\text { Calibration of models addressing climate } \\
\text { impacts at the landscape scale (LandClim, } \\
\text { mechanistic model of landscape dynamics). }\end{array}$ & & $\mathrm{x}$ & $\mathrm{x}$ & $\begin{array}{l}\text { Schumacher and Bugmann 2006, Elkin and } \\
\text { Bugmann 2010, Elkin et al. 2012, } 2013\end{array}$ \\
\hline & $\begin{array}{l}\text { Testing management options to increase stand } \\
\text { heterogeneity and tree resistance against drought. }\end{array}$ & & & $\mathrm{x}$ & Rigling et al. 2012, Elkin et al. 2013 \\
\hline Ecology \& & Modeling concomitant effects of climate and & & & $\mathrm{x}$ & Briner 2012, Briner et al. $2012 b$ \\
\hline Socioeconomics & $\begin{array}{l}\text { land-use change on the provision of ecosystem } \\
\text { goods and services. }\end{array}$ & & & & \\
\hline Socioeconomics & $\begin{array}{l}\text { Constructing consistent regional multiscale } \\
\text { scenarios by transdisciplinary processes. }\end{array}$ & & $\mathrm{x}$ & & Brand et al. 2012 \\
\hline \multirow[t]{2}{*}{ Policy } & $\begin{array}{l}\text { Role of network governance in enhancing } \\
\text { sustainable development in mountain areas. }\end{array}$ & $\mathrm{x}$ & & & Ingold et al. 2010, Hirschi 2010 \\
\hline & $\begin{array}{l}\text { Governance modes of adaptation measures in } \\
\text { Canton Valais. }\end{array}$ & $\mathrm{x}$ & & & Widmer and Hirschi, unpublished manuscript \\
\hline
\end{tabular}

$\mathrm{S}=$ (Field) Survey E $=$ Experiments $; \mathrm{M}=$ Modeling

at the stand scale was reduced, thus somewhat mitigating negative drought impacts. These alternative forest management practices are projected to influence both the absolute value of EGS and their spatio-temporal dynamics. The simulation of forest management scenarios in a forest landscape model, assuming elimination of a greater number of stems from the understory, resulted in a short-term decrease in structural forest diversity, but in the long run, thinning out of the understory proved to be a measure to mitigate climate change induced degradations. However, none of the alternative management scenarios that we tested were able to mitigate the strong decline in forest biomass and the related EGS at lower elevations. The magnitude of the decline depended significantly on the management regime.

The results from the above-mentioned forest model were combined with a socioeconomic land-use model integrating agricultural and forest land uses. Scenario assumptions such as price developments and policy measures strongly influenced the development of fodder and food provision in Valais under global change. However, some general trends emerged (Briner et al. 2012). For example, decreases in food production were found in all scenarios because of a large reduction in cropland and a concentration of food production on land with highly suitable soil and other desirable properties, e.g., flat or short distance to farm. This implies a trend toward a more intensive cultivation at low-elevation sites and less intensive cultivation at higher altitudes (Flury et al. 2013).

Land use and specifically climate change policies are characterized by their multilevel and multisectoral nature during formulation and implementation (Mickwitz et al. 2009). In the Visp region, a policy network analysis (Ingold et al. 2010) revealed how local communities are currently trying to adapt to climate change using the example of disaster risk management. The results show that horizontal, i.e., across jurisdictional scales, and vertical, i.e., across sectoral policies, integrations favor local communities' capacity to adapt to climate change. However, the quality of communication and participation drawing on social capital is equally important to create multilevel governance structures (Adger 2003). This finding is also supported by the transdisciplinary-based development of multiscale scenarios carried out by Brand et al. (2013) in this case study region. The results show that stakeholders' site-based knowledge and values are very important elements for broadening the range of apprehended 
Fig. 3. Illustrative example of forest ecosystem goods and services (EGS) trade-offs and heterogeneity arising from alternative management under climate change. Simulated impacts on the protective function that forests provide against gravitational hazards (a, b) and forest diversity (c, d) are shown. Projected changes in each EGS are represented as deviations from forest state in 2010. Intensive thinning, which is intended to increase forest vitality, initially decreased forests protective ability at intermediate and low elevations (a), but improved forest diversity (c). Later in the century intensive thinning is projected to increase the protective function of forests by facilitating a transition to more drought tolerant species. In contrast, understory thinning initially increases the protective ability of forests (b), but decreases forest diversity (d). Source: adapted from Rigling et al. 2012.

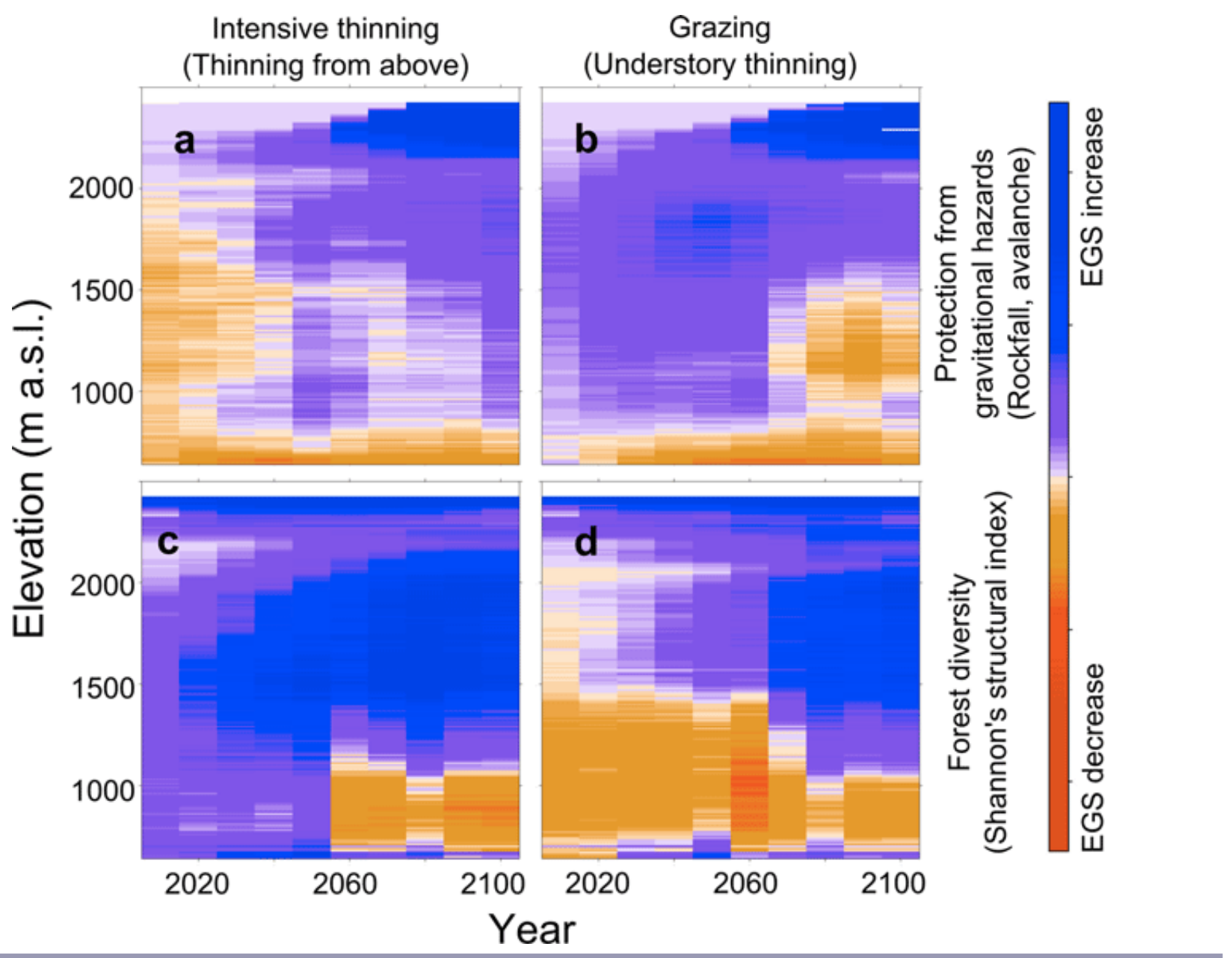

possibilities and developing strategies geared toward more desirable states in the future (Kok et al. 2007).

\section{Nonlinear dynamics and thresholds}

Species-specific biophysical thresholds underlie the mechanisms that will drive future changes in forest and grassland composition and structure. Nonlinear ecological responses to climate change are projected to result in EGS also exhibiting threshold responses (Rigling et al. 2012). The point in time when these thresholds will be reached depends mainly on the EGS and the location in the landscape (Briner et al. 2012). For example, the protective function forests provide against rock fall at lower altitudes changes only marginally between the years 2000 and 2050 in the simulations for Valais but decreases dramatically between 2060 and 2100 when drought years become more frequent. Such nonlinear changes along altitudinal gradients are also found with respect to agricultural EGS, albeit they are more susceptible and responsive to economic drivers.

\section{Heterogeneity}

In the dry, inner-alpine Valais region, the response of forest EGS to climate change was found to be heterogeneous in both space and time. The direction and rate of the response of forest 
Table 3. Research foci and methodologies temperature-sensitive inner Alpine region Davos.

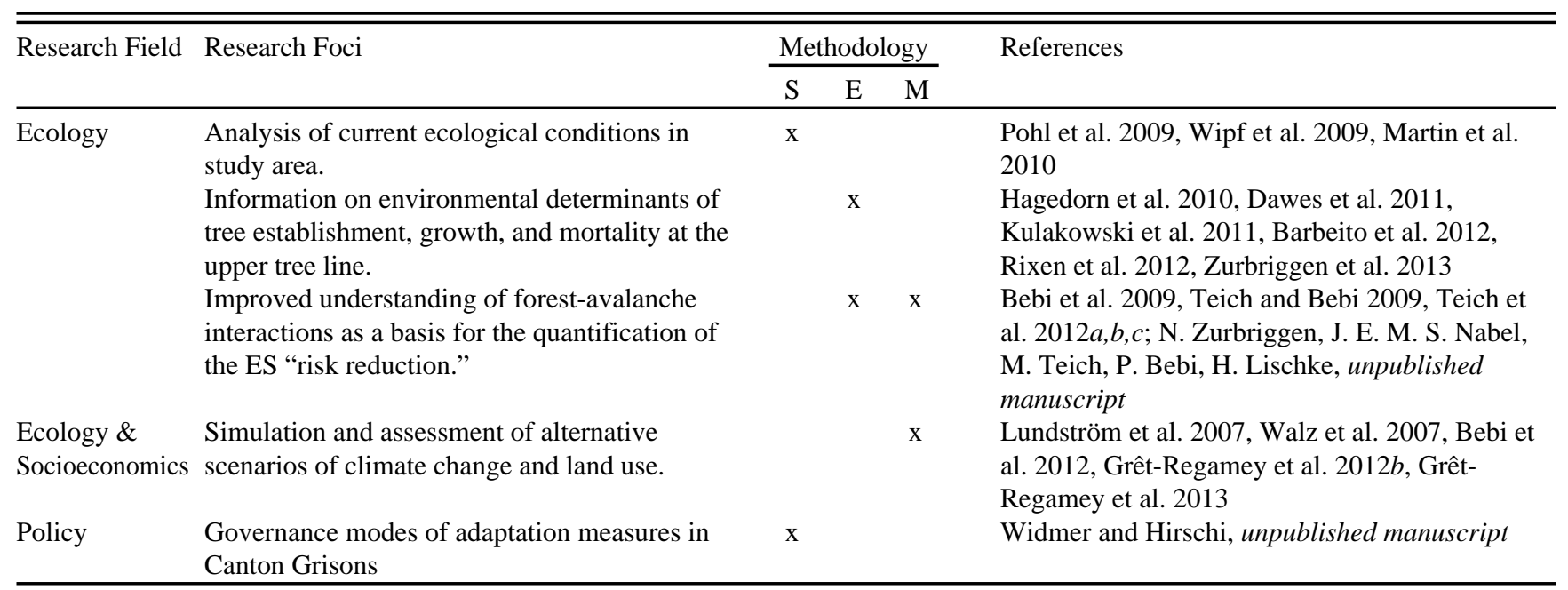

$\mathrm{S}=($ Field $)$ Survey $; \mathrm{E}=$ Experiments; $\mathrm{M}=$ Modeling

EGS to climate change depend strongly on the specific service: how it is quantified and where it is located between the foothills and upper tree line (Elkin and Bugmann 2010). For example, when assessed at the landscape scale, most biodiversity metrics representing land-use heterogeneity, show a general increase between 2000 and 2100, whereas the protection forests provide against gravitational hazards decreases at lower elevations, but increases toward the tree line over the same period (Fig. 3).

\section{Trade-offs}

Five relevant interactions between EGS were identified in our analyses. First, less intensive land uses that support the maintenance of biodiversity were found to result in a shortterm loss of income for local farmers. Second, where grazing prevents the expansion of forests that provide protection from natural hazards, there is a trade-off between agriculture and avalanche protection. Third, our results suggest that conserving biodiversity could be traded-off for carbon sequestration. Fourth, in contrast, a long-term synergy was found between an increase in the provision of protection from natural hazards, including avalanche protection, and carbon sequestration, also observed in the case study of Davos. Fifth, less intensive land use in mountain regions may reduce agricultural emissions, e.g., greenhouse gases, and simultaneously increase habitat quality (Briner et al. 2013).

\section{Feedback and feedback loops}

It was important to consider human and environmental thresholds jointly because our results implied that the combined effects could not have been derived as an average or sum of the isolated socioeconomic or ecological effects
(Briner 2012). Simulations suggest that forest EGS will be influenced strongly by climate change. Changes in land use, such as the abandonment of high alpine pastures or management practices such as thinning out or forest grazing, although still alleviating the expected impact of future drought, will have a comparatively smaller impact (Fig. 4). In contrast, changes in agricultural EGS are found to result primarily from shifts in economic conditions that alter land use and land management. Climate change was also simulated to influence agricultural EGS directly, but its relative importance was low. These trends continue even though the potential for agricultural production increases because of more favorable climatic conditions at currently temperaturelimited, higher elevations. Simulations project that an increase in grassland yields at these elevations would lead to reductions in cultivated land because of structural restrictions. Farmers who can feed an optimal number of animals with less land, and thus at less cost, will tend to abandon less suitable land.

\section{Summary}

The impact of climate change on forest development in dry regions, such as the inner-alpine Valais, is likely to be particularly strong, with marked long-term changes in tree composition and forest structure. Combined with land-use changes, the impact of climate change is projected to vary considerably depending on where EGS are evaluated within the landscape. The case study highlights the importance of combining different scales in the assessment of EGS provision in mountain regions (Verburg and Overmars 2009, van Delden et al. 2011). 
Fig. 4. Illustrative example of feedbacks of management and climate change on nonlinear tree mortality in the course of forest stand development. Clim(o) = climate today; Clim $(+)=$ climate change $;(\operatorname{Man}(\mathrm{o})=$ today's management; $\operatorname{Man}$ $(\mathrm{A})=$ adapted management. The diagram refers to Scots pine (Pinus sylvestris) growing in a dry environment and is derived from a simulation study including thinning and grazing/shrub removal (Elkin and Bugmann 2010).

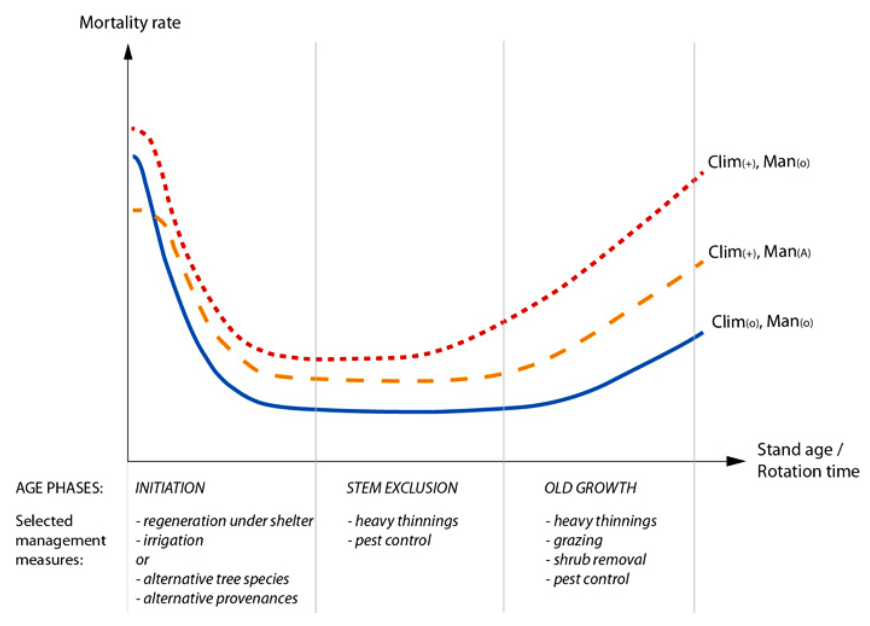

\section{TEMPERATURE-SENSITIVE, INNER-ALPINE REGION, DAVOS}

Avalanche protection and recreation are the most important forest EGS in the Davos region. In contrast to avalanche protection, the value of recreation is higher in open forests than in closed forests. Thus, the consideration of trade-offs between protection, recreation, and other EGS in the management of these mountain forests is a key challenge in this region. Table 3 summarizes the research foci, methodologies, and publications pertaining to the Davos region case study.

Davos has experienced an increase in forest cover over the last 50 years. A time series of aerial photographs shows how canopy cover has increased especially between $1600-2000 \mathrm{~m}$ a.s.l., i.e., $100-500 \mathrm{~m}$ below the current tree line (Kulakowski et al. 2009). With further climate warming, we expect this trend to be even more pronounced, with the tree line slowly and spatially heterogeneously shifting upward, although some of the currently thick forests at lower elevations may well decrease in density, depending on forest management and natural disturbances (Grêt-Regamey et al. 2013). In the case of the spatially heterogeneous upward shift of the tree line, experiments at Stillberg, an experimental area near the upper tree line above Davos, have shown that tree survival and growth are limited by several partly interrelated factors. As in the case of interactions between land-use practices and vegetation dynamics in the Jura case study region, the relative importance of factors limiting tree survival and growth change according to the tree's developmental stage. Early establishment of seedlings of a variety of tree species did not seem to be limited by current climatic conditions even beyond their actual upper distribution limit. In addition, environmental factors other than temperature, such as nitrogen availability, exert a strong influence on their biomass production and allocation (Zurbriggen et al. 2013). During the years 3 to 30 of their life, tree survival near the tree line is driven mainly by snow cover duration, although temperature is most important for growth (Barbeito et al. 2012). This suggests that small changes in the duration of snow cover and other environmental factors can have strong impacts on tree population dynamics, which in turn will affect EGS provision, foremost in avalanche protection.

In addition, we found that the responses of tree line trees to changes in environmental conditions are very species-specific, as also shown in the context of drought effects on trees in the Valais case study region. For example, experiments with $\mathrm{CO}_{2}$ enrichment and soil warming with 40 trees at Stillberg revealed a positive response to elevated $\mathrm{CO}_{2}$ for larch (Larix decidua), although mountain pine (Pinus mugo) showed no such response (Dawes et al. 2011). Soil warming, in contrast, did not affect growth or change the $\mathrm{CO}_{2}$ response in larch, although the ring widths and shoot lengths of pine were greater in warmed plots. For both species, warming led to $\mathrm{C}$ losses at the tree line, which exceeded the carbon accumulation estimated for the plants (Kammer et al. 2009, Hagedorn et al. 2010). In a warmer and $\mathrm{CO}_{2}$-enriched future, we can thus expect speciesspecific responses with potentially important impacts on forest cover and structure resulting in increased trade-offs in the provision of different EGS.

Avalanche protection is the most important EGS in about 50\% of the forests in the study area (Grêt-Regamey et al. 2013). Therefore, additional forest expansion and increases in forest cover density may further augment EGS, in particular if newly established forest patches are situated on steep slopes above densely populated areas (Bebi et al. 2009, Kulakowski et al. 2011). A GIS-based Bayesian network analysis showed that, in the future, the total value of EGS of forested ecosystems may increase in a climate warming scenario (Grêt-Regamey et al. 2013), mainly because of a further rise in the value of the EGS protection against natural hazards. However, the increase in forest cover is accompanied by a further loss of areas with low-intensity agricultural land use. This may have a negative impact on other EGS such as recreation or biodiversity (MacDonald et al. 2000, Lundström et al. 2007, Walz et al. 2007).

\section{Nonlinear dynamics and thresholds}

Experiments at the upper tree line in Davos show that tree growth and survival tend to be variable in space, time, and 
Fig. 5. Illustrative example of selected ecosystem services bundles in the tourism dominated region Davos under a trend and a climate change scenario. The figure shows a simulated spatial pattern of summed values of avalanche protection (aval), recreation (rec), carbon sequestration (CO2), habitat provision (hab), and timber production (timb) for two different forest areas. Priority ecosystem services exhibit the highest value in specific forest plots. Areas with avalanche protection as priority ecosystem service in yellow provide also recreation, C-sequestration, habitat services, and timber as ecosystem goods and services (EGS) of varying values. Areas with recreation as priority ecosystem service in green provide also Csequestration, habitat services and timber. Areas with C-sequestration as priority ecosystem service in blue provide also recreation and timber. Bundles of EGS are very similar in both scenarios (adapted from GrêtRegamey 2012a).

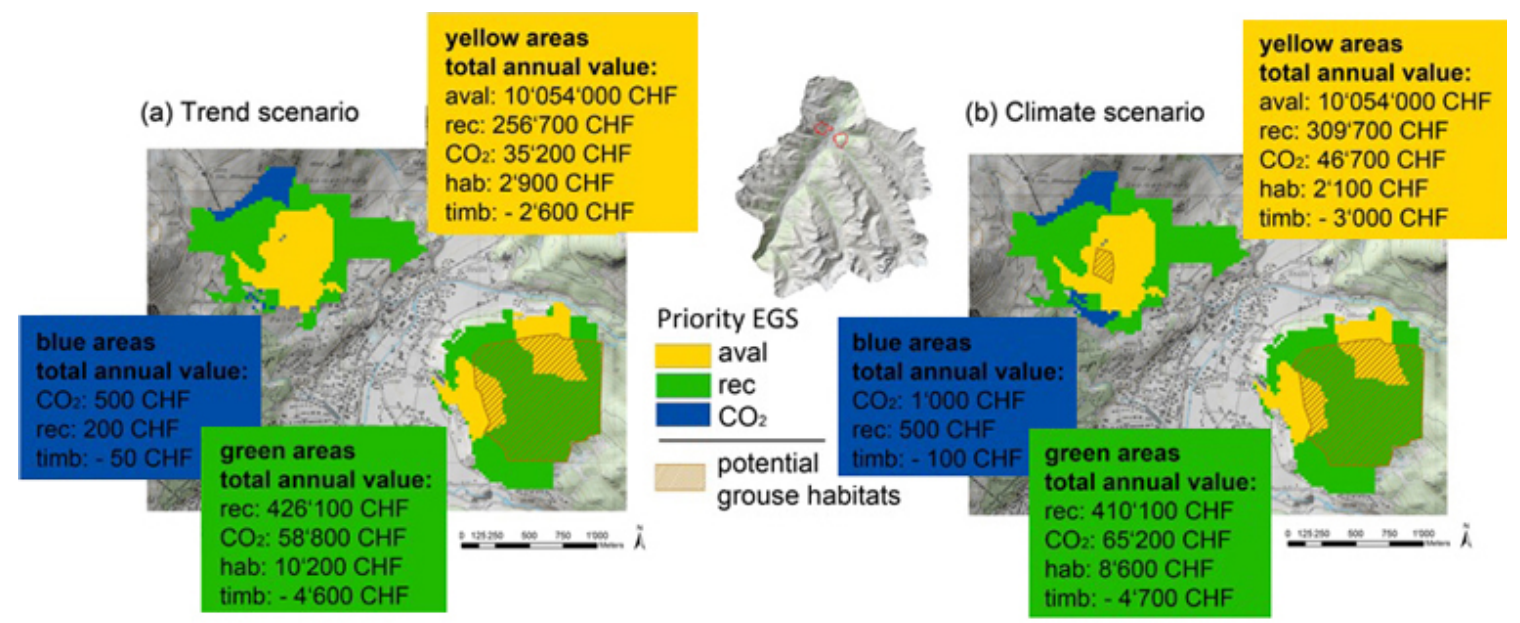

over the tree developmental stages because of the shifting relevance of environmental factors during the first 30 years of tree growth and the impact of variations in the duration of snow cover (Barbeito et al. 2012). When the indirect effects of temperature increase on the duration of snow cover, disturbance regimes and, in particular, the positive feedback between avalanches and forest dynamics (Kulakowski et al. 2011, Teich et al. 2012a) are also taken into consideration, predicted forest cover and the corresponding EGS will change nonlinearly. For example, simulation results imply that forest pseudoequilibrium will switch from forested to sparsely forested if avalanche-induced mortality exceeds a threshold on avalanche-prone slopes (Teich et al. 2012a). This diminishes the protection value of the forest and results in less $\mathrm{CO}_{2}$ sequestration.

\section{Heterogeneity}

At a smaller spatial scale, microtopography is very important for tree establishment, tree growth, and biodiversity at the upper tree line (Smit et al. 2005, Scherrer et al. 2011, Barbeito et al. 2012). The spatial heterogeneity and interannual variability of snow cover is an important driver of EGS, such as providing protection against avalanches (Teich et al. $2012 b$ ). In the case of the latter, forest cover upslope influences avalanche runout downslope, thus increasing spatial dependencies and variability. Canton Grisons has established an early warning and crisis management system for natural hazards to monitor such changes, taking climatic changes explicitly into account.

\section{Trade-offs}

In the tourism-dominated region of Davos, local trade-offs and synergies were found between avalanche protection, carbon sequestration, habitats for Capercaillie (Tetrao urogallus), and wood production. Although trade-offs between avalanche protection and recreation are most relevant at the regional scale, a spatial analysis revealed that the consideration of other trade-offs was also a key for defining spatially explicit forest management strategy (Grêt-Regamey et al. 2013). Current management takes into account spatial variations in protection against natural hazards. However, the cost efficiency of such measures could potentially be improved if other EGS were considered, to create win-win situations with better hazard protection and the provision of various other EGS (Fig. 5).

\section{Feedback and feedback loops}

As in the other case study regions, feedback effects in general increased spatial heterogeneity and subsequently trade-offs in EGS. For Davos, we found that the feedback mechanisms between forest cover changes, and natural disturbances often varies at small spatial scales. For example, in avalanche release 
zones, even small increases in tree density can considerably improve the protective effectiveness of a forest against avalanches. Even increases in the density of small trees $(<15$ $\mathrm{cm}$ DBH) in the starting zone have a significant effect on avalanche runout distances (Teich et al. 2012c).

\section{Summary}

In conclusion, experiments and models suggest that in temperature-limited, high-alpine ecosystems such as those in the region of Davos, changes in different EGS because of climate change will vary and not be easily predictable. The explicit simulation of the dynamics and mapping of EGS values to account for uncertainties will be a key to the development of spatially differentiated management strategies, and thus to the optimized allocation of resources to guarantee the provision of EGS (Grêt-Regamey et al. 2012a). In addition, the case study illustrates the need to explicitly address both supply and demand for EGS in mountain regions (Burkhard et al. 2012, Grêt-Regamey et al. 2012b).

\section{POLICY ASSESSMENT IN THE PRESENCE OF THRESHOLDS, HETEROGENEITY, FEEDBACKS, AND TRADE-OFFS}

Land-use policies that (could) steer adaptation to climate change in mountain regions span across all government levels of the Swiss federalist political system. Several coordinated activities across policy sectors have been adopted at the regional level to increase local adaptive capacities to address climatic and socioeconomic changes (Ingold et al. 2010).

In addition to such regional policies, forest and agricultural policy play a particularly crucial role because of the relatively large share of forested and agricultural land in mountain areas. These are traditional sectoral policies, mainly steered at the national level. Our analysis shows that these federal policies require less centralized and more flexible steering mechanisms to better respect the specific conditions of mountain regions (Hirschi et al. 2013; Hirschi and Widmer, unpublished manuscript). Recent reforms in these policy areas actually indicate developments in this direction. The federal parliament recently partially revised the federal forest law to make forest area policy more flexible from a regional point of view. In addition, direct payments for ecosystem services provided by the agricultural sector are to be expanded with the ongoing agricultural policy reform. However, studies from other policy areas show that a more cooperative and network-oriented approach could further enhance rural sustainability by strengthening the vertical cohesion between government levels (Hirschi 2010). This could guarantee the necessary flexibility to adapt to new ecological and socioeconomic developments that cannot be influenced directly by a region itself.

As our research results also imply, a successful implementation of such policy instruments and measures will depend heavily on the existing policy network (Hirschi et al. 2013). As with public policy making in general (Jones and Baumgartner 2005), land-use policy making is rooted in existing governance structures and therefore policy processes often exhibit strong path dependence (Duit and Galaz 2008). The human-environment systems interactions described above offer pathways toward a reconciliation between governance structures and the future provision of critical EGS in mountain regions.

\section{Nonlinear dynamics and thresholds}

After a long period of constant changes, users of natural resources may be confronted with rapid changes potentially including multiple ecological, economic, and social/cultural thresholds (Kinzig et al. 2006). Such thresholds are critical for the unfolding of negative impacts on ecosystems (RaudseppHearne et al. 2010). Thus, flexible forms of policy steering and multilevel governance systems are required (Folke et al. 2005). Instead of prescribing untargeted management measures, programs with a performance mandate in combination with a global budget are more suitable to secure the provision of mountain EGS. Such flexible forms of policy steering must be coordinated between sectoral policies to provide a set of policy options guaranteeing sufficient room for maneuvering in the event of abrupt changes and thus supporting the adaptive capacity of the people managing natural resources in mountain regions.

\section{Heterogeneity}

Spatial heterogeneity has myriad impacts on EGS provision (Turner et al. 2012). The heterogeneous impacts in time and space in our analysis point to the need for policy measures adapted to local conditions because a generalization of the effects can be misleading (Hanley et al. 2012). A partial regionalization of policy instruments would counteract the fact that a policy of 'everything everywhere,' particularly in the agricultural sector, has led to a certain monoculture of use, while at the same time neglecting regional potentials in the Swiss Alps (Lehmann and Messerli 2007). In addition, potential regionalization would increase the flexibility of adaptation strategies necessary for resilient development (Agrawal and Perrin 2009). A regionalization of policy instruments would also lead to a redistribution of financial support and compensation schemes (Flury et al. 2005), which Reed et al. (2009) also identified as a central option in the maintenance of EGS in the UK uplands, or as discussed by Lebel and Daniel (2009) in the context of payments for ecosystem services in tropical upland watersheds. Such a sitespecific allocation of financial resources is however not always possible under current sectoral and hierarchical policy mechanisms and may result in inefficient local solutions if regional or national boundary conditions are disregarded (Brondizio et al. 2009). 


\section{Trade-offs}

Given potential trade-offs between ecosystem services, policy makers should consider the cumulative and synergistic, or antagonistic, effects of their decisions (Rodríguez et al. 2006). Project-oriented, integrative policy measures, in contrast to isolated, sector-specific measures, support the consideration of trade-offs in managing EGS provision in mountain regions. In addition, specific projects, such as regional park projects or meliorations, permit the inclusion of stakeholders in the formulation and implementation of policy and management options. Within such cross-sectoral and multilevel governance projects, the management options analyzed in our assessment could be implemented in accordance with the key abiotic driving forces and in consideration of the specific mindset of stakeholders in respective areas (Lebel et al. 2006). In this context, our stakeholder workshops in Valais revealed that cultural heritage, local identity, and specific land-use traditions were firmly anchored in the mindset of the people. Consequently, the development of traditions and values are important aspects when considering and anticipating future development trajectories (Brand et al. 2013). Thus, including stakeholders in the formulation and implementation of policy and management options could help people retain these traditions and support social resilience (Adger 2000, Wiek et al. 2012).

\section{Feedback and feedback loops}

A better understanding of the feedback between humans and ecosystems is essential for the management of EGS provision (Carpenter et al. 2009a). In our findings, positive feedback and feedback loops amplified the probability of thresholds, increased the heterogeneity of climate change impacts, and influenced trade-offs in EGS provision. There are no blueprint policies that would allow us to reconcile all these challenges (Ostrom 2009). However, spatial planning with an adequate consideration of multiple stakeholders is increasingly seen as a key coordination instrument in European mountain regions and elsewhere (de Groot et al. 2010). For example, Lebel and Daniel (2009) concluded from their review in tropical uplands that multistakeholder planning exercises may not eliminate the importance of interests or power relations, but do improve the quality of assessments of services and users. The stakeholder workshops in the Visp region case study showed that the people living in the region tended to consider spatial planning as the most "active" factor affecting their future (Brand et al. 2013). The heterogeneity in the future provision of EGS illustrated in our case studies implies that the creation of new categories, in addition to the existing zoning categories, representing the spatially explicit different levels of risk and vulnerability, would increase the effectiveness and efficiency of adaptation measures.

\section{DISCUSSION}

Without an understanding of the biophysical reality, any assessment of the impact of climate and land-use change on the provision of EGS is futile (Seppelt et al. 2011, Carpenter et al. 2009a). The analysis in Mountland illustrates the effects of a changing biophysical context on the growth of specific tree species, fodder production, or changes in soil carbon cycling in experimental settings simulating climate change. Common research questions (Huber et al. 2013b) and scenarios permit the experimental findings to be upscaled to relevant spatial levels, where the provision of EGS can be taken into account in management and/or (political) decision making (Müller et al. 2010). The linkage of socioeconomic and ecological models in Mountland allows a successful exploration of a range of scenarios designed to quantify the impacts and trade-offs of EGS provision in mountain regions under a joint set of assumptions. Scenario analyses are associated with uncertainties and surprises (Carpenter et al. 2009b). Model-based trajectories of future developments are uncertain by definition and thus should not be interpreted as predictions (Carpenter et al. 2006). However, the linkage of different models allowed an examination of the major issues identified in the different case study regions: (1) a quantification of the concomitant effects of climate and landuse changes in EGS provision, which was exemplified by the Jura case study; (2) a spatially explicit integration of data from different scales, which was most pressing in the Valais region case study; and (3) the identification of trade-offs in the provision of EGS, which was of specific importance in the Davos region case study. Furthermore, the presentation of maps, trade-off curves, and balance sheets to stakeholders allowed for the anchoring of our interdisciplinary research findings in a transdisciplinary dialogue. This represents an important step toward a harmonization in the supply and demand of EGS.

Linking to the literature on coupled human and natural systems and EGS (Liu et al. 2007b, Alberti et al. 2011, Scholz 2011), we found the following key characteristics of such systems to be central to our case study areas in European mountain regions: nonlinearities and thresholds; heterogeneity; and trade-offs, as well as feedback. We found relevant examples of these characteristics in all three case study regions. Our results suggest that an institutional framework focusing on three aspects is essential for maintaining and strengthening important EGS in mountain regions. First, integrative approaches, i.e., policy integration, to strengthen crosssectoral coordination should be supported (Weber 2007). These approaches would allow for a more effective provision of mountain EGS in the presence of heterogeneity and thresholds. Second, network management and steering, i.e., network governance, to strengthen multilevel governance (Lebel et al. 2006, Kok and Veldkamp 2011) would permit an adequate integration of (local) stakeholders in policy formulation and implementation processes. Spatial planning instruments and methods addressing heterogeneity, trade-offs, and feedback provide important policy alternatives in this context (Reed et al. 2009). Third, the integration of 
stakeholders would permit a focus on capacity building (Folke et al. 2010). This is important to reduce vulnerability to changing climate conditions, socioeconomic developments, and related risks that we identified in Mountland.

Two major challenges make the implementation of such policy measures difficult. First, the strong path dependence that we identified in the current sectoral policies implies that major policy reforms in the agricultural sector are unlikely, unless there is substantial political pressure from other economically powerful sectors and/or broader national or international political developments (Sciarini 1994, Hirschi et al. 2013). Although (perceived) crises may represent windows of opportunity to navigate social-ecological transitions (Folke 2006, Olsson et al. 2008), this will often result in conflicts with the traditions and values of local stakeholders because high levels of collective action and learning often mean overriding institutional features such as path dependency (Duit and Galaz 2008). Consequently, governance systems may have to include both flexible and stable elements at the same time (Duit et al. 2010). Monitoring of policies and projects is important to reveal (dis-) advantages of different governance systems supporting the provision of EGS in mountain regions. Second, the spatial and temporal variability of climate change impacts and the uncertainty associated with climate change make the implementation of policy measures difficult because the long-term frame required exceeds by far the normal election and budgetary cycles of the political administrative system (Cash et al. 2006). Thus, the main challenge and scientific obligation are to provide policy makers with visions and scenarios of possible developments before these ecological effects become visible in the landscape.

Responses to this article can be read online at:

http://www.ecologyandsociety.org/issues/responses.

$\mathrm{php/5499}$

\section{Acknowledgments:}

This work was supported by the Competence Center Environment and Sustainability of the Swiss Federal Institute of Technology as part of the Mountland project. We are grateful to the members of the stakeholder advisory groups of the three study regions. Many thanks to Silvia Dingwall and Jennifer Bays for English corrections. This study is dedicated to the memory of our friend and admired scientist Matthias Dobbertin who tragically passed away before our joint research projects were completed.

\section{LITERATURE CITED}

Abildtrup, J., E. Audsley, M. Fekete-Farkas, C. Giupponi, M. Gylling, P. Rosato, and M. Rounsevell. 2006. Socio-economic scenario development for the assessment of climate change impacts on agricultural land use: a pairwise comparison approach. Environmental Science and Policy 9:101-115. http://dx.doi.org/10.1016/j.envsci.2005.11.002

Adger, W. N. 2000. Social and ecological resilience: are they related? Progress in Human Geography 24:347-364. http://dx. doi.org/10.1191/030913200701540465

Adger, W. N. 2003. Social capital, collective action, and adaptation to climate change. Economic Geography 79:387-404. http://dx.doi.org/10.1111/j.1944-8287.2003.tb00220. $\underline{\mathrm{X}}$

Agrawal, A., and N. Perrin. 2009. Climate adaptation, local institutions and rural livelihoods. Pages 350-367 in W. N. Adger, I. Lorenzoni, and K. O'Brien, editors. Adapting to climate change: thresholds, values, governance. Cambridge University Press, Cambridge, UK. http://dx.doi.org/10.1017/ CBO9780511596667.023

Alberti, M., H. Asbjornsen, L. A. Baker, N. Brozovic, L. E. Drinkwater, S. A. Drzyzga, C. A. Jantz, J. Fragoso, D. S. Holland, T. A. Kohler, J. Liu, W. J. McConnell, H. D. G. Maschner, J. D. A. Millington, M. Monticino, G. Podestà, R. G. Pontius, Jr., C. L. Redman, N. J. Reo, D. Sailor, and G. Urquhart. 2011. Research on coupled human and natural systems (CHANS): approach, challenges, and strategies. Bulletin of the Ecological Society of America 92:218-228. http://dx.doi.org/10.1890/0012-9623-92.2.218

Allen, V. G., C. Batello, E. J. Berretta, J. Hodgson, M. Kothmann, X. Li, J. McIvor, J. Milne, C. Morris, A. Peeters, M. Sanderson, and The Forage and Grazing Terminology Committee. 2011. An international terminology for grazing lands and grazing animals. Grass and Forage Science 66:2-28. http://dx.doi.org/10.1111/j.1365-2494.2010.00780.x

Allen, C. D., A. K. Macalady, H. Chenchouni, D. Bachelet, N. McDowell, M. Vennetier, T. Kitzberger, A. Rigling, D. D. Breshears, E. H. Hogg, P. Gonzalez, R. Fensham, Z. Zhang, J. Castro, N. Demidova, J.-H. Lim, G. Allard, S. W. Running, A. Semerci, and N. Cobb. 2010. A global overview of drought and heat-induced tree mortality reveals emerging climate change risks for forests. Forest Ecology and Management 259:660-684. http://dx.doi.org/10.1016/j.foreco.2009.09.001

Barbeito, I., M. A. Dawes, C. Rixen, J. Senn, and P. Bebi. 2012. Factors driving mortality and growth at treeline: a 30year experiment of 92000 conifers. Ecology 93(2):389-401. http://dx.doi.org/10.1890/11-0384.1

Bebi, P., D. Kulakowski, and C. Rixen. 2009. Snow avalanche disturbances in forest ecosystems: state of research and implications for management. Forest Ecology and Management 257:1883-1892. http://dx.doi.org/10.1016/j. foreco.2009.01.050 
Bebi, P., M. Teich, F. Hagedorn, N. Zurbriggen, S. H. Brunner, and A. Grêt-Regamey. 2012. Veränderung von wald und waldleistungen in der landschaft Davos im zuge des klimawandels. Schweizerische Zeitschrift für Forstwesen 12:493-501. http://dx.doi.org/10.3188/szf.2012.0493

Bigler, C., O. U. Bräker, H. Bugmann, M. Dobbertin, and A. Rigling. 2006. Drought as an inciting mortality factor in Scots pine stands of the Valais, Switzerland. Ecosystems 9:330-343. http://dx.doi.org/10.1007/s10021-005-0126-2

Brand, F. S., R. Seidl, Q. B. Le, J. Brändle, and R. W. Scholz. 2013. Constructing consistent multiscale scenarios by transdisciplinary processes: the case of mountain regions facing global change. Ecology and Society 18(2): 43. http:// dx.doi.org/10.5751/ES-04972-180243

Briner, S. 2012. Provision of ecosystem goods and services by agriculture and forestry in mountainous regions of Switzerland. Dissertation. Eidgenössische Technische Hochschule, ETH, Zurich, Switzerland. [online] URL: http:// e-collection.library.ethz.ch/eserv/eth:6154/eth-6154-02.pdf

Briner, S., C. Elkin, R. Huber, and A. Grêt-Regamey. 2012. Assessing the impacts of economic and climate changes on land-use in mountain regions: a spatial dynamic modeling approach. Agriculture, Ecosystems and Environment 149:50-63. http://dx.doi.org/10.1016/j.agee.2011.12.011

Briner, S., R. Huber, P. Bebi, D. R. Schmaltz, C. Elkin, and A. Grêt-Regamey. 2013. Trade-offs between ecosystem services in mountainous regions. Ecology and Society 18(3): 35. http://dx.doi.org/10.5751/ES-05576-180335

Brondizio, E. S., E. Ostrom, and O. R. Young. 2009. Connectivity and the governance of multilevel socialecological systems: the role of social capital. Annual Review of Environment and Resources 34:253-278. http://dx.doi. org/10.1146/annurev.environ.020708.100707

Brunner, I., E. G. Pannatier, B. Frey, A. Rigling, W. Landolt, S. Zimmermann, and M. Dobbertin. 2009. Morphological and physiological responses of Scots pine fine roots to water supply in a dry climatic region in Switzerland. Tree Physiology 29:541-550. http://dx.doi.org/10.1093/treephys/tpn046

Bugmann, H., A. B. Gurung, F. Ewert, W. Haeberli, A. Guisan, D. Fagre, A. Kääb, and Glochamore participants. 2007. Modeling the biophysical impacts of global change in mountain biosphere reserves. Mountain Research and Development 27:66-77. http://dx.doi.org/10.1659/0276-4741 (2007)27[66:MTBIOG]2.0.CO;2

Burkhard, B., F. Kroll, S. Nedkov, and F. Müller. 2012. Mapping ecosystem service supply, demand and budgets. Ecological Indicators 21:17-29. http://dx.doi.org/10.1016/j. ecolind.2011.06.019

Buttler, A., F. Kohler, and F. Gillet. 2009. The Swiss mountain wooded pastures: patterns and processes. Pages 377-396 in A.
Rigueiro-Rodriguez, J. McAdam, and M. R. MosqueraLosada, editors. Agroforestry in Europe: current status and future prospects. Springer, New York, New York, USA.

Buttler, A., T. Spiegelberger, J. Chételat, T. Kalbermatten, K. Lannas, A. Peringer, J.-B. Wettstein, and F. Gillet. 2012. Évolution récente et future des paysages sylvo-pastoraux du Jura vaudois. Schweizerische Zeitschrift für Forstwesen 163:469-480. http://dx.doi.org/10.3188/szf.2012.0469

Carpenter, S. R., E. M. Bennett, and G. D. Peterson. 2006. Scenarios for ecosystem services: an overview. Ecology and Society 11(1): 29. [online] URL: http://www.ecologyandsociety. org/vol11/iss1/art29/

Carpenter, S. R., C. Folke, M. Scheffer, and F. Westley. $2009 b$. Resilience: accounting for the noncomputable. Ecology and Society 14(1): 13. [online] URL: http://www.ecologyandsociety. org/vol14/iss1/art13/

Carpenter, S. R., H. A. Mooney, J. Agard, D. Capistrano, R. S. DeFries, S. Diaz, T. Dietz, A. K. Duraiappah, A. OtengYeboah, H. M. Pereira, C. Perrings, W. V. Reid, J. Sarukhan, R. J. Scholes, and A. Whyte. 2009a. Science for managing ecosystem services: beyond the millennium ecosystem assessment. Proceedings of the National Academy of Sciences 106:1305-1312. http://dx.doi.org/10.1073/pnas.0808772106

Cash, D. W., W. N. Adger, F. Berkes, P. Garden, L. Lebel, P. Olsson, L. Pritchard, and O. Young. 2006. Scale and crossscale dynamics: governance and information in a multilevel world. Ecology and Society 11(2): 8. [online] URL: http:// www.ecologyandsociety.org/vol11/iss2/art8/

Chételat, J., M. Kalbermatten, K. S. M. Lannas, T. Spiegelberger, J.-B. Wettstein, F. Gillet, A. Peringer, and A. Buttler. 2013. A contextual analysis of observed land-use and vegetation changes applied in two wooded pastures in the Swiss Jura Mountains. Ecology and Society 18(1): 39. http:// dx.doi.org/10.5751/ES-05287-180139

Claessens, L., J. M. Schoorl, P. H. Verburg, L. Geraedts, and A. Veldkamp. 2009. Modelling interactions and feedback mechanisms between land use change and landscape processes. Agriculture, Ecosystems and Environment 129:157-170. http://dx.doi.org/10.1016/j.agee.2008.08.008

Dawes, M. A., S. Hättenschwiler, P. Bebi, F. Hagedorn, I. T. Handa, C. Körner, and C. Rixen. 2011. Species-specific tree growth responses to 9 years of $\mathrm{CO}_{2}$ enrichment at the alpine treeline. Journal of Ecology 99:383-394. http://dx.doi. org/10.1111/j.1365-2745.2010.01764.X

de Groot, R. S., R. Alkemade, L. Braat, L. Hein, and L. Willemen. 2010. Challenges in integrating the concept of ecosystem services and values in landscape planning, management and decision making. Ecological Complexity 7:260-272. http://dx.doi.org/10.1016/j.ecocom.2009.10.006 
Dobbertin, M., B. Eilmann, P. Bleuler, A. Giuggiola, E. Graf Pannatier, W. Landolt, P. Schleppi, and A. Rigling. 2010. Effect of irrigation on needle morphology, shoot and stem growth in a drought-exposed Pinus sylvestris forest. Tree Physiology 30:346-360. http://dx.doi.org/10.1093/treephys/ tpp123

Dufour, A., Z. Gadallah, H. H. Wagner, A. Guisan, and A. Buttler. 2006. Plant species richness and environmental heterogeneity in a mountain landscape: effects of variability and spatial configuration. Ecography 29:573-584. http://dx. doi.org/10.1111/j.0906-7590.2006.04605.x

Duit, A., and V. Galaz. 2008. Governance and complexity emerging issues for governance theory. Governance 21:311-335. http://dx.doi.org/10.1111/j.1468-0491.2008.00402. $\underline{\mathrm{x}}$

Duit, A., V. Galaz, K. Eckerberg, and J. Ebbesson. 2010. Governance, complexity, and resilience. Global Environmental Change 20:363-368. http://dx.doi.org/10.1016/j.

gloenvcha.2010.04.006

Eilmann, B., N. Buchmann, R. Siegwolf, M. Saurer, P. Cherubini, and A. Rigling. 2010. Fast response of Scots pine to improved water availability reflected in tree-ring width and 813C. Plant, Cell and Environment 33:1351-1360. http://dx. doi.org/10.1111/j.1365-3040.2010.02153.x

Eilmann, B., and A. Rigling. 2012. Tree-growth analyses to estimate tree species' drought tolerance. Tree Physiology 32:178-187. http://dx.doi.org/10.1093/treephys/tps004

Eilmann, B., R. Zweifel, N. Buchmann, E. Graf Pannatier, and A. Rigling. 2011. Drought alters timing, quantity, and quality of wood formation in Scots pine. Journal of Experimental Botany 62(8):2763-2771. http://dx.doi.org/10.1093/jxb/erq443

Elkin, C., and H. Bugmann. 2010. Impact of climate change on ecosystem services in the Valais, Switzerland. Pages 67-69 in G. W. Hazeu, L. F. S. Roupioz, and M. Perez-Soba, editors. Europe's ecological backbone: recognising the true value of our mountains. European Environment Agency, Copenhagen, Denmark.

Elkin, C., B. Reineking, C. Bigler, and H. Bugmann. 2012. Do small-grain processes matter for landscape scale questions? Sensitivity of a forest landscape model to the formulation of tree growth rate. Landscape Ecology 27:697-711. http://dx.doi.org/10.1007/s10980-012-9718-3

Elkin, C., A. G. Gutiérrez, S. Leuzinger, C. Manusch, C. Temperli, L. Rasche, and H. Bugmann. 2013. A $2{ }^{\circ} \mathrm{C}$ warmer world is not safe for ecosystem services in the European Alps. Global Change Biology 19:1827-1840. http://dx.doi. org/10.1111/gcb.12156
Flury, C., N. Gotsch, and P. Rieder. 2005. Site-specific and regionally optimal direct payments for mountain agriculture. Land Use Policy 22:207-214. http://dx.doi.org/10.1016/j. landusepol.2004.02.003

Flury, C., R. Huber, and E. Tasser. 2013. Future of mountain agriculture in the Alps. Pages 105-126 in S. Mann, editor. The future of mountain agriculture. Springer Verlag, Berlin, Germany. http://dx.doi.org/10.1007/978-3-642-33584-6 8

Folke, C. 2006. Resilience: the emergence of a perspective for social-ecological systems analyses. Global Environmental Change 16:253-267. http://dx.doi.org/10.1016/j.

gloenvcha.2006.04.002

Folke, C., S. R. Carpenter, B. Walker, M. Scheffer, T. Chapin, and J. Rockström. 2010. Resilience thinking: integrating resilience, adaptability and transformability. Ecology and Society 15(4): 20. [online] URL: http://www.ecologyandsociety. org/vol15/iss4/art20/

Folke, C., T. Hahn, P. Olsson, and J. Norberg. 2005. Adaptive governance of social-ecological systems. Annual Review of Environment and Resources 30:441-473. http://dx.doi. org/10.1146/annurev.energy.30.050504.144511

Gavazov, K. S., A. Peringer, A. Buttler, F. Gillet, and T. Spiegelberger. 2013. Dynamics of forage production in pasture-woodlands of the Swiss Jura Mountains under projected climate change scenarios. Ecology and Society 18 (1): 38. http://dx.doi.org/10.5751/ES-04974-180138

Gillet, F. 2008. Modelling vegetation dynamics in heterogeneous pasture-woodland landscapes. Ecological Modelling 217:1-18. http://dx.doi.org/10.1016/j.

ecolmodel.2008.05.013

Gillet, F., F. Kohler, C. Vandenberghe, and A. Buttler. 2010. Effect of dung deposition on small-scale patch structure and seasonal vegetation dynamics in mountain pastures. Agriculture, Ecosystems and Environment 135:34-41. http:// dx.doi.org/10.1016/j.agee.2009.08.006

Gillet, F., B. Murisier, A. Buttler, J.-D. Gallandat, and J.-M. Gobat. 1999. Influence of tree cover on the diversity of herbaceous communities in subalpine wooded pastures. Applied Vegetation Science 2:47-54. http://dx.doi. org/10.2307/1478880

Gimmi, U., T. Wohlgemuth, A. Rigling, C. W. Hoffmann, and M. Bürgi. 2010. Land-use and climate effects in forest compositional trajectories in a dry central-alpine valley. Annals of Forest Science 67:701. http://dx.doi.org/10.1051/ forest/2010026

Grêt-Regamey, A., S. H. Brunner, J. Altwegg, and P. Bebi. 2012b. Facing uncertainty in ecosystem services-based 
resource management. Journal of Environmental Management 127:S145-S154. [online] URL: http://www.sciencedirect. com/science/article/pii/S0301479712003921

Grêt-Regamey, A., S. H. Brunner, J. Altwegg, M. Christen, and P. Bebi. 2013. Integrating expert knowledge into mapping ecosystem services trade-offs for sustainable forest management. Ecology and Society 18(3): 34. http://dx.doi. org/10.5751/ES-05800-180334

Grêt-Regamey, A., S. H. Brunner, and F. Kienast. 2012a. Mountain ecosystems services: who cares? Mountain Research and Development 32:23-34. http://dx.doi. org/10.1659/MRD-JOURNAL-D-10-00115.S1

Hagedorn, F., M. Martin, C. Rixen, S. Rusch, P. Bebi, A. Zürcher, R. T. W. Siegwolf, S. Wipf, C. Escape, J. Roy, and S. Hättenschwiler. 2010. Short-term responses of ecosystem carbon fluxes to experimental soil warming at the Swiss alpine treeline. Biogeochemistry 97:7-19. http://dx.doi.org/10.1007/ s10533-009-9297-9

Hanley, N., S. Acs, M. Dallimer, K. J. Gaston, A. Graves, J. Morris, and P. R. Armsworth. 2012. Farm-scale ecological and economic impacts of agricultural change in the uplands. Land Use Policy 29:587-597. http://dx.doi.org/10.1016/j. landusepol.2011.10.001

Hazeu, G. W., L. F. S. Roupioz, and M. Perez-Soba, editors. 2010. Europe's ecological backbone: recognising the true value of our mountains. European Environmental Agency, Copenhagen, Denmark. [online] URL: http://www.eea. europa.eu/publications/europes-ecological-backbone

Heiniger, U., F. Theile, A. Rigling, and D. Rigling. 2011. Bluestain infections in roots, stems and branches of declining Pinus sylvestris trees in a dry inner alpine valley in Switzerland. Forest Pathology 41:501-509. http://dx.doi.org/10.1111/ j.1439-0329.2011.00713.x

Hirschi, C. 2010. Strengthening regional cohesion: collaborative networks and sustainable development in Swiss rural areas. Ecology and Society 15(4): 16. [online] URL: http://www.ecologyandsociety.org/vol15/iss4/art16/

Hirschi, C., A. Widmer, S. Briner, and R. Huber. 2013. Combining policy network and model-based scenario analyses: an assessment of future ecosystem goods and services in Swiss mountain regions. Ecology and Society 18 (2): 42. http://dx.doi.org/10.5751/ES-05480-180242

Huber, R., P. Bebi, S. Briner, H. Bugmann, A. Buttler, A. GrêtRegamey, C. Hirschi, W. Zimmermann, and A. Rigling. 2012. Waldausdehnung in zwei regionen des Schweizer berggebiets: eine integrative analyse aus sicht der land- und forstwirtschaft. Schweizerische Zeitschrift für Forstwesen 163:502-511. http://dx.doi.org/10.3188/szf.2012.0502

Huber, R., S. Briner, A. Peringer, S. Lauber, R. Seidl, A. Widmer, F. Gillet, A. Buttler, Q. B. Le, and C. Hirschi. $2013 b$.
Modeling social-ecological feedback effects in the implementation of payments for environmental services in pasture-woodlands. Ecology and Society 18(2): 41. http://dx. doi.org/10.5751/ES-05487-180241

Huber, R., H. Bugmann, A. Buttler, and A. Rigling. $2013 a$. Sustainable land-use practices in European mountain regions under global change: an integrated research approach Ecology and Society 18(3): 37. http://dx.doi.org/10.5751/ES-05375-180337

Ingold, K., J. Balsiger, and C. Hirschi. 2010. Climate change in mountain regions: how local communities adapt to extreme events. Local Environment 15:651-661. http://dx.doi. org/10.1080/13549839.2010.498811

Jones, B. D., and F. R. Baumgartner. 2005. The politics of attention: how government prioritizes problems. University of Chicago Press, Chicago, Illinois, USA.

Kammer, A., F. Hagedorn, I. Shevchenko, J. Leifeld, G. Guggenberger, T. Goryacheva, A. Rigling, and P. Moiseev. 2009. Treeline shifts in the Ural mountains affect soil organic matter dynamics. Global Change Biology 15:1570-1583. http://dx.doi.org/10.1111/j.1365-2486.2009.01856.x

Kinzig, A. P., P. Ryan, M. Etienne, H. Allison, T. Elmqvist, and B. H. Walker. 2006. Resilience and regime shifts: assessing cascading effects. Ecology and Society 11(1): 20. [online] URL: http://www.ecologyandsociety.org/vol11/iss1/ $\underline{\operatorname{art20/}}$

Kohler, F., F. Gillet, J.-M. Gobat, and A. Buttler. $2004 a$. Seasonal vegetation changes in mountain pastures due to simulated effects of cattle grazing. Journal of Vegetation Science 15:143-150. http://dx.doi.org/10.1111/j.1654-1103.2004. tb02249.x

Kohler, F., F. Gillet, J.-M. Gobat, and A. Buttler. 2006b. Effect of cattle activities on gap colonization in mountain pastures. Folia Geobotanica 41:289-304. http://dx.doi.org/10.1007/ BF02904943

Kohler, F., F. Gillet, M. A. Progin, J.-M. Gobat, and A. Buttler. $2004 b$. Seasonal dynamics of plant species at fine scale in wooded pastures. Community Ecology 5:7-17. http://dx.doi. org/10.1556/ComEc.5.2004.1.2

Kohler, F., F. Gillet, S. Reust, H. H. Wagner, F. Gadallah, J.M. Gobat, and A. Buttler. 2006a. Spatial and seasonal patterns of cattle babitat use in a mountain wooded pasture. Landscape Ecology 21:281-295. http://dx.doi.org/10.1007/s10980-005-0144-7

Kok, K., R. Biggs, and M. Zurek. 2007. Methods for developing multiscale participatory scenarios: insights from southern Africa and Europe. Ecology and Society 12(1): 8. [online] URL: http://www.ecologyandsociety.org/vol12/iss1/ $\underline{\operatorname{art} 81}$

Kok, K., and T. (A.) Veldkamp. 2011. Scale and governance: conceptual considerations and practical implications. Ecology 
and Society 16(2): 23. [online] URL: http://www. ecologyandsociety.org/vol16/iss2/art23/

Kulakowski, D., P. Bebi, and C. Rixen. 2011. The interacting effects of land use change, climate change and suppression of natural disturbances on landscape forest structure in the Swiss Alps. Oikos 120:216-225. http://dx.doi.org/10.1111/ j.1600-0706.2010.18726.x

Kurz, W. A., C. C. Dymond, G. Stinson, G. J. Rampley, E. T. Neilson, A. L. Carroll, T. Ebata, and L. Safranyik. 2008. Mountain pine beetle and forest carbon feedback to climate change. Nature 452:987-990. http://dx.doi.org/10.1038/ nature 06777

Lebel, L., J. M. Anderies, B. Campbell, C. Folke, S. HatfieldDodds, T. P. Hughes, and J. Wilson. 2006. Governance and the capacity to manage resilience in regional social-ecological systems. Ecology and Society 11(1): 19. [online] URL: http:// www.ecologyandsociety.org/vol11/iss1/art19/

Lebel, L., and R. Daniel. 2009. The governance of ecosystem services from tropical upland watersheds. Current Opinion in Environmental Sustainability 1:61-68. http://dx.doi.org/10.1016/ j.cosust.2009.07.008

Lehmann, B., and P. Messerli. 2007. The Swiss National Research Programme: "landscapes and habitats of the alpine arc." Journal of Alpine Research 4:19-28. [online] URL: http:// rga.revues.org/344?lang=en

Liu, J., T. Dietz, S. R. Carpenter, M. Alberti, C. Folke, E. Moran, A. N. Pell, P. Deadman, T. Kratz, J. Lubchenco, E. Ostrom, Z. Ouyang, W. Provencher, C. L. Redman, S. H. Schneider, and W. W. Taylor. 2007b. Complexity of coupled human and natural systems. Science 317:1513-1516. http://dx. doi.org/10.1126/science.1144004

Liu, J., T. Dietz, S. R. Carpenter, C. Folke, M. Alberti, C. L. Redman, S. H. Schneider, E. Ostrom, A. N. Pell, J. Lubchenco, W. W. Taylor, Z. Ouyang, P. Deadman, T. Kratz, and W. Provencher. 2007a. Coupled human and natural systems. AMBIO 36:639-649. http://dx.doi.org/10.1579/0044-7447 (2007)36[639:CHANS]2.0.CO;2

Lundström, C., S. Kytzia, A. Walz, A. Grêt-Regamey, and P. Bebi. 2007. Linking models of land use, resources, and economy to simulate the development of mountain regions (ALPSCAPE). Environmental Management 40:379-393. http://dx.doi.org/10.1007/s00267-005-0342-8

MacDonald, D., J. R. Crabtree, G. Wiesinger, T. Dax, N. Stamou, P. Fleury, J. Gutierrez Lazpita, and A. Gibon. 2000. Agricultural abandonment in mountain areas of Europe: environmental consequences and policy response. Journal of Environmental Management 59:47-69. http://dx.doi.org/10.1006/ jema.1999.0335
Malcolm, J. R., C. Liu, R. P. Neilson, L. Hansen, and L. Hannah. 2006. Global warming and extinctions of endemic species from biodiversity hotspots. Conservation Biology 20:538-548. http://dx.doi.org/10.1111/j.1523-1739.2006.00364. $\underline{x}$

Marini, L., S. Klimek, and A. Battisti. 2011. Mitigating the impacts of the decline of traditional farming on mountain landscapes and biodiversity: a case study in the European Alps. Environmental Science and Policy 14:258-267. http://dx.doi. org/10.1016/j.envsci.2010.12.003

Martin, M., K. Gavazov, C. Körner, S. Hättenschwiler, and C. Rixen. 2010. Reduced early growing season freezing resistance in alpine treeline plants under elevated atmospheric $\mathrm{CO}_{2}$. Global Change Biology 16:1057-1070. http://dx.doi. org/10.1111/j.1365-2486.2009.01987.x

McCain, C. M., and R. K. Colwell. 2011. Assessing the threat to montane biodiversity from discordant shifts in temperature and precipitation in a changing climate. Ecology Letters 14:1236-1245. http://dx.doi.org/10.1111/j.1461-0248.2011.01695. $\underline{\mathrm{X}}$

Metzger, M. J., M. D. A. Rounsevell, L. Acosta-Michlik, R. Leemans, and D. Schröter. 2006. The vulnerability of ecosystem services to land use change. Agriculture, Ecosystems and Environment 114:69-85. http://dx.doi. org/10.1016/j.agee.2005.11.025

Mickwitz, P., F. Aix, S. Beck, D. Carss, N. Ferrand, C. Görg, A. Jensen, P. Kivimaa, C. Kuhlicke, W. Kuindersma, M. Máñez, M. Melanen, S. Monni, A. B. Pedersen, H. Reinert, and S. van Bommel. 2009. Climate policy integration, coherence and governance. Partnership for European Environmental Research, Helsinki, Findland.

Millennium Ecosystem Assessment (MEA). 2005. Ecosystems and human well-being: synthesis. Island, Washington, D.C., USA. [online] URL: http://www.unep.org/maweb/documents/ document.356.aspx.pdf

Moser, B., C. Temperli, G. Schneiter, and T. Wohlgemuth. 2010. Potential shift in tree species composition after interaction of fire and drought in the central Alps. European Journal of Forest Research 129:625-633. http://dx.doi. org/10.1007/s10342-010-0363-6

Müller, F., R. de Groot, and L. Willemen. 2010. Ecosystem services at the landscape scale: the need for integrative approaches. Landscape Online 23:1-11. [online] URL: http:// www.landscapeonline.de/archive/2010/23/

Nogués-Bravo, D., M. B. Araújo, M. P. Errea, and J. P. Martinez-Rica. 2007. Exposure of global mountain systems to climate warming during the 21st Century. Global Environmental Change 17:420-428. http://dx.doi.org/10.1016/ j.gloenvcha.2006.11.007 
Olsson, P., C. Folke, and T. P. Hughes. 2008. Navigating the transition to ecosystem-based management of the Great Barrier Reef, Australia. Proceedings of the National Academy of Sciences 105:9489-9494. http://dx.doi.org/10.1073/ pnas.0706905105

Ostrom, E. 2009. A general framework for analyzing sustainability of social-ecological systems. Science 325:419-422. http://dx.doi.org/10.1126/science.1172133

Peringer, A., S. Siehoff, J. Chételat, T. Spiegelberger, A. Buttler, and F. Gillet. 2013. Past and future landscape dynamics in pasture-woodlands of the Swiss Jura Mountains under climate change. Ecology and Society 18(3): 11. http:// dx.doi.org/10.5751/ES-05600-180311

Pohl, M., D. Alig, C. Körner, and C. Rixen. 2009. Higher plant diversity enhances soil stability in disturbed alpine ecosystems. Plant and Soil 324:91-102. http://dx.doi. org/10.1007/s11104-009-9906-3

Polasky, S., E. Nelson, J. Camm, B. Csuti, P. Fackler, E. Lonsdorf, C. Montgomery, D. White, J. Arthur, B. GarberYonts, R. Haight, J. Kagan, A. Starfield, and C. Tobalske. 2008. Where to put things? Spatial land management to sustain biodiversity and economic returns. Biological Conservation 141:1505-1524. http://dx.doi.org/10.1016/j.biocon.2008.03.022

Raudsepp-Hearne, C., G. D. Peterson, and E. M. Bennett. 2010. Ecosystem service bundles for analyzing tradeoffs in diverse landscapes. Proceedings of the National Academy of Sciences 107:5242-5247. http://dx.doi.org/10.1073/pnas.0907284107

Reed, M. S., A. Bonn, W. Slee, N. Beharry-Borg, J. Birch, I. Brown, T. P. Burt, D. Chapman, P. J. Chapman, G. D. Clay, S. J. Cornell, E. D. G. Fraser, J. H. Glass, J. Holden, J. A. Hodgson, K. Hubacek, B. Irvine, N. Jin, M. J. Kirkby, W. E. Kunin, O. Moore, D. Moseley, C. Prell, M. F. Price, C. H. Quinn, S. Redpath, C. Reid, S. Stagl, L. C. Stringer, M. Termansen, S. Thorp, W. Towers, and F. Worrall. 2009. The future of the uplands. Land Use Policy 26:S204-S216. http:// dx.doi.org/10.1016/j.landusepol.2009.09.013

Richter, S., T. Kipfer, T. Wohlgemuth, C. Calderón Guerrero, J. Ghazoul, and B. Moser. 2012. Phenotypic plasticity facilitates resistance to climate change in a highly variable environment. Oecologia 169(1):269-279 http://dx.doi. org/10.1007/s00442-011-2191-X

Rigling, A., C. Bigler, B. Eilmann, E. Feldmeyer-Christe, U. Gimmi, C. Ginzler, U. Graf, P. Mayer, G. Vacchiano, P. Weber, T. Wohlgemuth, R. Zweifel, and M. Dobbertin. 2013. Driving factors of a vegetation shift from Scots pine to pubescent oak in dry alpine forests. Global Change Biology 19:229-240. http://dx.doi.org/10.1111/gcb.12038
Rigling, A., B. Eilmann, R. Koechli, and M. Dobbertin. 2010. Mistletoe-induced crown degradation in Scots pine in a xeric environment. Tree Physiology 30:845-852. http://dx.doi. org/10.1093/treephys/tpq038

Rigling, A., C. Elkin, M. Dobbertin, B. Eilmann, A. Giuggiola, T. Wohlgemuth, and H. Bugmann. 2012. Wald und klimawandel in der inneralpinen trockenregion Visp. Schweizerische Zeitschrift für Forstwesen 12:481-492. http:// dx.doi.org/10.3188/szf.2012.0481

Rixen, C., M. A. Dawes, S. Wipf, and F. Hagedorn. 2012. Evidence of enhanced freezing damage in treeline plants during six years of $\mathrm{CO}_{2}$ enrichment and soil warming. Oikos 121:1532-1543. http://dx.doi.org/10.1111/j.1600-0706.2011.20031. $\underline{\mathrm{X}}$

Rodríguez, J. P., T. D. Beard, Jr., E. M. Bennett, G. S. Cumming, S. J. Cork, J. Agard, A. P. Dobson, and G. D. Peterson. 2006. Trade-offs across space, time, and ecosystem services. Ecology and Society 11(1): 28. [online] URL: http:// www.ecologyandsociety.org/vol11/iss 1/art28/

Rounsevell, M. D. A., I. Reginster, M. B. Araújo, T. R. Carter, N. Dendoncker, F. Ewert, J. I. House, S. Kankaanpää, R. Leemans, M. J. Metzger, C. Schmit, P. Smith, and G. Tuck. 2006. A coherent set of future land use change scenarios for Europe. Agriculture, Ecosystems and Environment 114:57-68. http://dx.doi.org/10.1016/j.agee.2005.11.027

Scherrer, D., S. Schmid, and C. Körner. 2011. Elevational species shifts in a warmer climate are overestimated when based on weather station data. International Journal of Biometeorology 55:645-654. http://dx.doi.org/10.1007/ s00484-010-0364-7

Scholz, R. W. 2011. Environmental literacy in science and society: from knowledge to decisions. Cambridge University Press, Cambridge, UK. http://dx.doi.org/10.1017/ CBO9780511921520

Scholz, R. W., and F. S. Brand. 2011. Comparing the HES framework with alternative appraoches. Pages 509-524 in R. W. Scholz, editor. Environmental literacy in science and society. Cambridge University Press, Cambridge, UK.

Schröter, D., W. Cramer, R. Leemans, I. C. Prentice, M. B. Araújo, N. W. Arnell, A. Bondeau, H. Bugmann, T. R. Carter, C. A. Gracia, A. C. de la Vega-Leinert, M. Erhard, F. Ewert, M. Glendining, J. I. House, S. Kankaanpää, R. J. T. Klein, S. Lavorel, M. Lindner, M. J. Metzger, J. Meyer, T. D. Mitchell, I. Reginster, M. Rounsevell, S. Sabaté, S. Sitch, B. Smith, J. Smith, P. Smith, M. T. Sykes, K. Thonicke, W. Thuiller, G. Tuck, S. Zaehle, and B. Zierl. 2005. Ecosystem service supply and vulnerability to global change in Europe. Science 310:1333-1337. http://dx.doi.org/10.1126/science.1115233 
Schumacher, S., and H. Bugmann. 2006. The relative importance of climatic effects, wildfires and management for future forest landscape dynamics in the Swiss Alps. Global Change Biology 12:1435-1450. http://dx.doi.org/10.1111/ j.1365-2486.2006.01188.x

Sciarini, P. 1994. La Suisse face à la communauté Européenne et au GATT: le cas test de la politique agricole. Georg, Genève, Switzerland.

Seppelt, R., C. F. Dormann, F. V. Eppink, S. Lautenbach, and S. Schmidt. 2011. A quantitative review of ecosystem service studies: approaches, shortcomings and the road ahead. Journal of Applied Ecology 48:630-636. http://dx.doi.org/10.1111/ j.1365-2664.2010.01952.x

Smit, C., D. Béguin, A. Buttler, and H. Müller-Schärer. 2005. Safe sites for tree regeneration in wooded pastures: a case of associational resistance? Journal of Vegetation Science 16:209-214. http://dx.doi.org/10.1111/j.1654-1103.2005.tb02357. $\underline{x}$

Teich, M., P. Bartelt, A. Grêt-Regamey, and P. Bebi. $2012 b$. Snow avalanches in forested terrain: influence of forest parameters, topography and avalanche characteristics on runout distance. Arctic, Antarctic, and Alpine Research 44:509-519. http://dx.doi.org/10.1657/1938-4246-44.4.509

Teich, M., and P. Bebi. 2009. Evaluating the benefit of avalanche protection forest with GIS-based risk analyses: a case study in Switzerland. Forest Ecology and Management 257:1910-1919. http://dx.doi.org/10.1016/j.foreco.2009.01.046

Teich, M., C. Marty, C. Gollut, A. Grêt-Regamey, and P. Bebi. 2012c. Snow and weather conditions associated with avalanche releases in forests: rare situations with decreasing trends during the last 41 years. Cold Regions Science and Technology 83-84:77-88. http://dx.doi.org/10.1016/j. coldregions.2012.06.007

Teich, M., N. Zurbriggen, P. Bartelt, A. Grêt-Regamey, C. Marty, M. Ulrich, and P. Bebi. 2012a. Potential impacts of climate change on snow avalanches starting in forested terrain. Pages 244-251 in Proceedings of the International Snow Science Workshop, Anchorage, Alaska, USA. [online] URL: http://www.slf.ch/ueber/mitarbeiter/homepages/marty/publications/ Teich2012_ForestAvalanches_CC.pdf

Turner, M. G., D. C. Donato, and W. H. Romme. 2012. Consequences of spatial heterogeneity for ecosystem services in changing forest landscapes: priorities for future research. Landscape Ecology April 2012:1-17. http://dx.doi.org/10.1007/ s10980-012-9741-4

van Delden, H., J. van Vliet, D. T. Rutledge, and M. J. Kirkby. 2011. Comparison of scale and scaling issues in integrated land-use models for policy support. Agriculture, Ecosystems and Environment 142:18-28. http://dx.doi.org/10.1016/j. agee.2011.03.005
Vandenberghe, C., F. Freléchoux, and A. Buttler. 2008. The influence of competition from herbaceous vegetation and shade on simulated browsing tolerance of coniferous and deciduous saplings. Oikos 117:415-423. http://dx.doi. org/10.1111/j.2007.0030-1299.16264.X

Vandenberghe, C., F. Freléchoux, F. Gadallah, and A. Buttler. 2006. Competitive effects of herbaceous vegetation on tree seedling emergence, growth and survival: does gap size matter? Journal of Vegetation Science 17:481-488. http://dx. doi.org/10.1111/j.1654-1103.2006.tb02469.x

Vandenberghe, C., F. Freléchoux, M.-A. Moravie, F. Gadallah, and A. Buttler. 2007. Short-term effects of cattle browsing on tree sapling growth in mountain wooded pastures. Plant Ecology 188:253-264. http://dx.doi.org/10.1007/ s11258-006-9160-1

Vandenberghe, C., C. Smit, M. Pohl, A. Buttler, and F. Freléchoux. 2009. Does the strength of facilitation by nurse shrubs depend on grazing resistance of tree saplings? Basic and Applied Ecology 10:427-436. http://dx.doi.org/10.1016/ j.baae.2008.08.009

Verburg, P. H., and K. P. Overmars. 2009. Combining topdown and bottom-up dynamics in land use modeling: exploring the future of abandoned farmlands in Europe with the Dyna-CLUE model. Landscape Ecology 24:1167-1181. http://dx.doi.org/10.1007/s10980-009-9355-7

Walz, A., C. Lardelli, H. Behrendt, A. Grét-Regamey, C. Lundström, S. Kytzia, and P. Bebi. 2007. Participatory scenario analysis for integrated regional modelling. Landscape and Urban Planning 81:114-131. http://dx.doi. org/10.1016/j.landurbplan.2006.11.001

Weber, J.-L. 2007. Implementation of land and ecosystem accounts at the European Environment Agency. Ecological Economics 61:695-707. http://dx.doi.org/10.1016/j. ecolecon.2006.05.023

Weber, P., H. Bugmann, P. Fonti, and A. Rigling. $2008 a$. Using a retrospective dynamic competition index to reconstruct forest succession. Forest Ecology and Management 254:96-106. http://dx.doi.org/10.1016/j. foreco.2007.07.031

Weber, P., A. Rigling, and H. Bugmann. 2008b. Sensitivity of stand dynamics to grazing in mixed Pinus sylvestris and Quercus pubescens forests: a modelling study. Ecological Modelling 210:301-311. http://dx.doi.org/10.1016/j. ecolmodel.2007.08.013

Wermelinger, B., A. Rigling, D. Schneider Mathis, and M. Dobbertin. 2008. Assessing the role of bark- and wood-boring insects in the decline of Scots pine (Pinus sylvestris) in the Swiss Rhone valley. Ecological Entomology 33:239-249. http://dx.doi.org/10.1111/j.1365-2311.2007.00960.x 
Wiek, A., B. Ness, P. Schweizer-Ries, F. S. Brand, and F. Farioli. 2012. From complex systems analysis to transformational change: a comparative appraisal of sustainability science projects. Sustainability Science 7:5-24. http://dx.doi.org/10.1007/s11625-011-0148-y

Wipf, S., V. Stoeckli, and P. Bebi. 2009. Winter climate change in alpine tundra: plant responses to changes in snow depth and snowmelt timing. Climatic Change 94:105-121. http://dx.doi.org/10.1007/s10584-009-9546-x

Zimmermann, P., E. Tasser, G. Leitinger, and U. Tappeiner. 2010. Effects of land-use and land-cover pattern on landscapescale biodiversity in the European Alps. Agriculture, Ecosystems and Environment 139:13-22. http://dx.doi. org/10.1016/j.agee.2010.06.010

Zurbriggen, N., S. Hättenschwiler, E. S. Frei, F. Hagedorn, and P. Bebi. 2013. Performance of germinating tree seedlings below and above treeline in the Swiss Alps. Plant Ecology 214:385-396. http://dx.doi.org/10.1007/s11258-013-0176-Z

Zweifel, R., A. Rigling, and M. Dobbertin. 2009. Speciesspecific stomatal response of trees to drought: a link to vegetation dynamics? Journal of Vegetation Science 20:442-454. http://dx.doi.org/10.1111/j.1654-1103.2009.05701. 